\title{
A geological field trip \\ to the Côte d'Ivoire-Ghana \\ transform margin
}

Jean MASCLE ', Michel GUIRAUD ${ }^{2 *}$, Jean BENKHELIL ${ }^{3}$, Christophe BASILE ${ }^{4}$, Jean-Pierre BOUILLIN ${ }^{4}$, Georges MASCLE ${ }^{4}$, Michel COUSIN $^{5}$, Marc DURAND ${ }^{2}$, Jean DEJAX ${ }^{6}$, Michel MOULLADE ${ }^{7}$

1 Observatoire Océanologique de Villefranche, UMR 6526, Géosciences Azur, BP 48, 06235 Villefranche-sur-Mer cedex, France.

${ }^{2}$ Laboratoire de Géologie des Ensembles Sédimentaires, Université de Nancy (URA CNRS 157), BP 239, 54505 Vandœuvre-les-Nancy, France.

* Centre des Sciences de la Terre, Université de Bourgogne, 6 boulevard Gabriel, 21000 Dijon, France.

3 Laboratoire de Sédimentologie et Géochimie Marines (URA CNRS 715), 52 avenue de Villeneuve, 66860 Perpignan, France.

${ }^{4}$ Institut Dolomieu, Université de Grenoble (ERS CNRS 129), 15 rue Maurice Gignoux, 38031 Grenoble, France.

5 Laboratoire de Géodynamique, Université de Chambéry (ERS CNRS 129), 74000 Chambéry, France.

${ }^{6}$ Laboratoire de Paléontologie du Muséum National d'Histoire Naturelle (URA CNRS 12), 8 ruc Buffon, 75005 Paris, France.

${ }^{7}$ Laboratoire de Micropaléontologie et Géologie Marines, Université de Nice (URA CNRS 327 et GDR 88), Parc Valrose, 06108 Nice, France.

Received 10/12/96, in revised form 27/06/97, accepted 11/07/97.

\section{ABSTRACT}

During the Equanaute survey (June 1992), fourteen submersible dives were performed between 4950 and $2250 \mathrm{~m}$ water depths across the southern slope of the Côte d'Ivoire-Ghana Marginal Ridge (CIGMR), in the eastern Equatorial Atlantic. The CIGMR, a high-standing topographic marginal ridge along the Côte d'Ivoire-Ghana transform margin, is believed to result from a complex structural evolution due to the specific wrench-related rifting between Western Equatorial Africa and Northeastern Brazil, in Early Cretaceous times. In this paper we report and discuss geological observations made during dives, and sample analyses to resolve the lithology, paleoenvironmental conditions, age and origin of the CIGMR. The data help in better characterizing the different sedimentary and tectonic regimes which successively prevailed during the CIGMR formation and assessing the thermal regime operative during the fabrication and subsequent evolution of the margin. The thick sedimentary pile exposed along the southern CIGMR slope is made up of a repetitive clastic sequence indicative of a deltaicto-prodeltaic environment. This sedimentary pile, of Early Cretaceous age, has recorded different stages of the transform margin structural evolution.

(1) Syn- to post-lithification deformations first record extensional deformations related to the rifting of the adjacent northern divergent margin segment (the Deep Ivorian Basin).

(2) Wrench tectonics has, at a later stage, produced intense fracturing and participated in local folding, chiefly detected upslope. The integrated studies of geological samples and in situ observations obtained during the Equanaute survey support models for transform margin evolution proposed mainly from geophysical data. (C) Elsevier, Paris. 
RÉSUMÉ
Analyse in situ d'un segment de marge transformante: plongées scientifiques sur la marge de Côte d'Ivoire-Ghana.

Au cours de la campagne Equanaute (juin 1992) quatorze plongées, effectuées à bord du Nautile entre 4950 et 2250 mètres de profondeur, ont pcrmis d'étudier la pente méridionale de la Ride de Côte d'Ivoire-Ghana (Atlantique équatorial). Cette Ride, qui constitue le long de ce segment de marge un relief linéaire important, est le résultat d'une évolution structurale spécifique liée à un rifting de type transformant entre Afrique de l'ouest et Nordeste brésilien au cours du Crêtacé infërieur.

Dans cet article nous décrivons et discutons les résultats géologiques provenant à la fois des observations en plongées et des études sur les échantillons géologiques récoltés. Ces données permettent de mieux comprendre les conditions du paléoenvironnement, l'âge et les différents épisodes tectoniques actuellement enregistrés dans les sédiments indurés affleurant tout au long de la pente observée. Les résultats permettent aussi d'évaluer les conditions thermiques contemporaines de la création de la Ride marginale, puis de son évolution ultérieure. L'épaisse série sédimentaire terrigène est, pour l'essentiel, constituée de dépôts cycliques vraisemblablement déposés dans un environnement de type deltaïque et de prodelta.

Cet ensemble sédimentaire, d'âge Crétacé inférieur, a enregistré différents épisodes de déformation: une déformation, contemporaine de la lithification, apparaît caractéristique d'un régime extensif accompagnant la création du segment de marge divergent voisin, l'actuel bassin profond de Côte d'Ivoire. Une déformation de type cisaillant a, par la suite, produit une importante fracturation et a abouti localement à la mise en place de plis, décelables surtout vers le haut de la pente explorée. Ces résultats d'ordre géologique sont en bon accord avec un modèle d'évolution de la marge transformante déduit de données géophysiques recueillies antérieurement. (C) Elsevier, Paris.

\section{NOTE}

Cet article, synthèse d'observations géologiques provenant de plongées du Nautile en 1992, a été rédigé avant la réalisation de la campagne ODP 159 (1995). Les auteurs n'en ont pas modifié la teneur dans la mesure où leurs observations et conclusions ne sont en rien contredites par les résultats de cette campagne de forage.

Oceanologica Acta, 1998, 21, 1, 1-20.

\section{INTRODUCTION}

Compared with volcanic or divergent continental margins, which also result from continental break-up, transform margins show many specific characteristics. They include: (a) a very rapid ocean-continent transition (of the order of a few kilometres); (b) a complex history of uplift and subsidence; (c) a tectonic history influenced by transform motion between two breaking plates; (d) a high input of clastic sediments as a consequence of rapid subsidence and active transform tectonics; (e) a subsequent sedimentation strongly triggered by structural damming effects (Mascle and Blarez, 1987).

One of the best examples of transform margins extends off Equatorial Africa, between the Côte d'Ivoire and eastern Ghana (Fig. 1). There, the Côte d'Ivoire-Ghana Continental Margin is a consequence of major transform motions between the African and Brazilian continental lithospheres in Early Cretaceous times (Mascle, 1976; Basile et al., 1993). Today, the transform motion between the two plates is still active within the Equatorial Atlantic, along the Romanche Fracture Zone which offsets the Mid-Atlantic Ridge by almost $1000 \mathrm{~km}$ (Honnorez et al., 1991) (Fig. 1).

A quite complete set of marine geological and geophysical data has already been obtained on this transform margin segment (Basile et al., 1996), including noteworthy data concerning its sedimentary records and tectonics (Mascle et al., 1988; Basile et al., 1993). However, detailed geological data, relating for example to sediment types, as well as information on environmental conditions, deformation styles and precise dating were very scarce and insufficient to help in better substantiating transform margin evolutionary processes.

In June 1992, during the Equanaute cruise, the Côte d'Ivoire-Ghana Marginal Ridge (CIGMR) was surveyed by the deep-sea submersible Nautile from IFREMER, operating from the R.V. Nadir. The area of investigation was focused on the steep CIGMR southern slope (Fig. 2). Today a high-standing morphologic feature, the CIGMR 
Figure 1

Sketch of the Equatorial Atlantic fractures zones and associated continental margins. The continental margin off the Côte d'Ivoire and Ghana are genetically associated to the Romanche Fracture Zone. The dotted box locates the Côte d'IvoireGhana transform margin area.

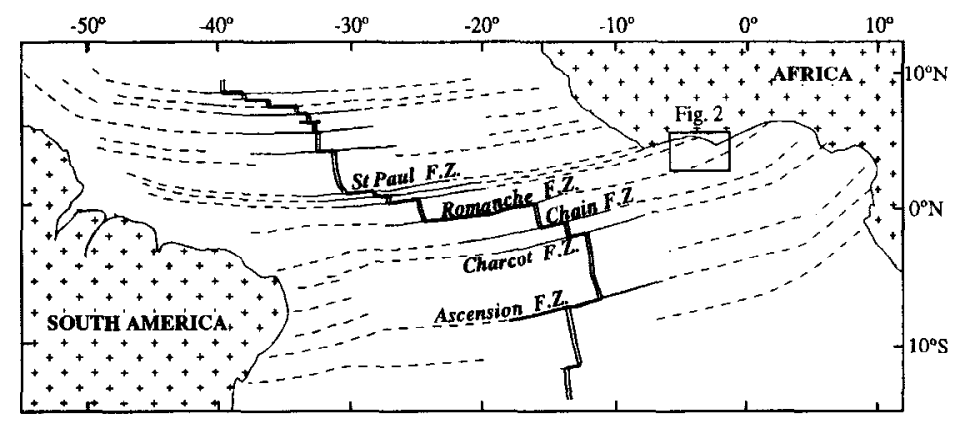

is thought to represent a wrench-tectonically deformed sediment wedge, located in sharp transition between an extensional margin (the Deep Ivorian Basin) to the north and the southern oceanic crust (the Gulf of Guinea abyssal plain) (Fig. 2). The setting of the present-day Marginal Ridge includes a fossil buried ridge that connects laterally, towards the south-west with the extinct Romanche Fracture Zone, and towards the north-east with the steep Ghanaian slope (Blarez, 1986; Mascle et al., 1988; Basilc et al., 1993). In this paper, we present and discuss, in the light of previous geophysical results, a synthesis of collected data and subsequent analyses, and propose a reconstruction of the sedimentary and deformational histories of the CIGMR. The data have been collected during 14 deep dives performed between water depths of 4950 and $2250 \mathrm{~m}$ (Mascle et al., 1994) (Figs. 3, 4). A total of 80 hours of in situ observations and continuous video records allowed the construction of 14 geological cross sections. These observations were completed by the recovery of 165 rock samples (including a few in situ oriented) retrieved along a total distance of about $75 \mathrm{~km}$ visited on the sea floor (Mascle et al., 1994).

The main objectives of the deep dive Equanaute survey were: (1) to collect rock samples across the CIGMR steep southern slope in order better to resolve its lithology, ascertain its nature and determine its age; (2) to characterize the successive tectonic regimes which contributed to generate the CIGMR (extensional, wrench

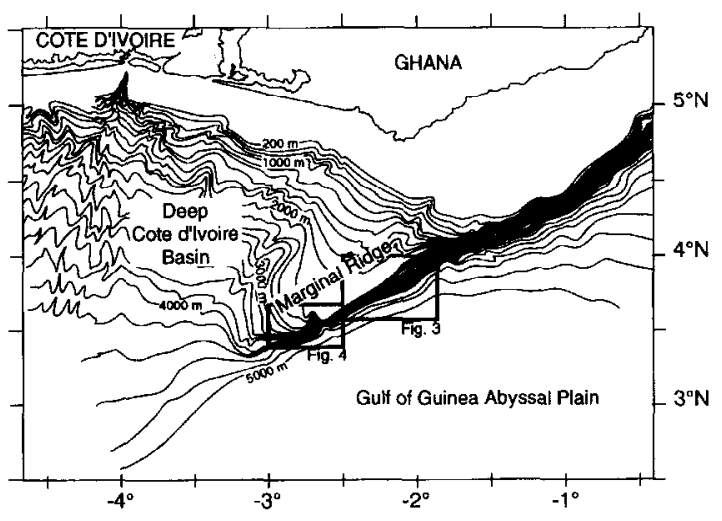

Figure 2

General bathymetric map of the Côte d'Ivoire-Ghana margin; contour lines in metres (after Blarez, 1986). Boxes locate Figures 3 and 4. tectonics, gravitational collapse); (3) to assess the past thermal regime which may have likely been operating and recorded within the CIGMR sediment pile as a consequence of its proximity to the oceanic crust.

\section{GEOPHYSICAL AND GEOLOGICAL SETTING OF THE CIGMR AND SURROUNDING AREAS}

\section{Bathymetry}

A general bathymetric map of offshore Côte-d'Ivoire and Ghana (Blarez, 1986) (Fig. 2) shows several morphologic domains. These are from north to south: (a) a relatively narrow continental shelf (only a few kilometres off Côte d'Ivoire to about $70 \mathrm{~km}$ off Ghana; (b) a well developed continental slope and rise known as the Deep Ivorian Basin; (c) the prominent (up to $2010 \mathrm{~m}$ depth) South-west to north-east trending CIGMR, which bounds towards the southern most point of the Ivorian Basin and rises, locally by more than $3000 \mathrm{~m}$, above the adjacent southern Gulf of Guinea Abyssal Plain (5000 m depth on average). Eastwards, the ridge connects with the very steep Ghanaian continental slope, while towards the southwest it progressively deepens and passes to a series of aligned small-scale abyssal hills, on a trend with the fossil Romanche Fracture Zone.

Detailed swath bathymetric maps collected during a previous survey (Mascle et al., 1989), cover respectively the CIGMR eastern corner, most of the CIGMR itself and parts of the adjacent Deep Ivorian Basin (Figs. 3, 4). On morphological grounds the investigated slope can be divided, from east to west, into four distinct domains: (a) An eastern domain exhibits, between 2000 and 4000 $m$ water depth, a rather gentle slope $\left(20^{\circ}\right.$ on average) dissected by several normally sloping valleys. Equanaute dives EN01 to EN03 (Fig. 3) were made across these valleys. The area is almost entirely covered by thin recent muddy sediments and only upslope shows a few rocky scarps where outcrops have been observed and sampled; (h) A central domain, disconnected from the previous one by a deep cross-cutting canyon. In this area, the steep slope is almost rectilinear and very regular, $\mathrm{N} 65^{\circ} \mathrm{E}$ trending, and has been investigated by Equanaute dives EN04 to EN06 and EN11 (Fig. 3). The slope averages $50^{\circ}$ and locally vertical cliffs exist; (c) A third slope domain lies just south of the marginal ridge top, which culminates at $2010 \mathrm{~m}$ water depth (Fig. 4). In this area the slope is cut by several very steep, north-south trending promontories. Equanaute 


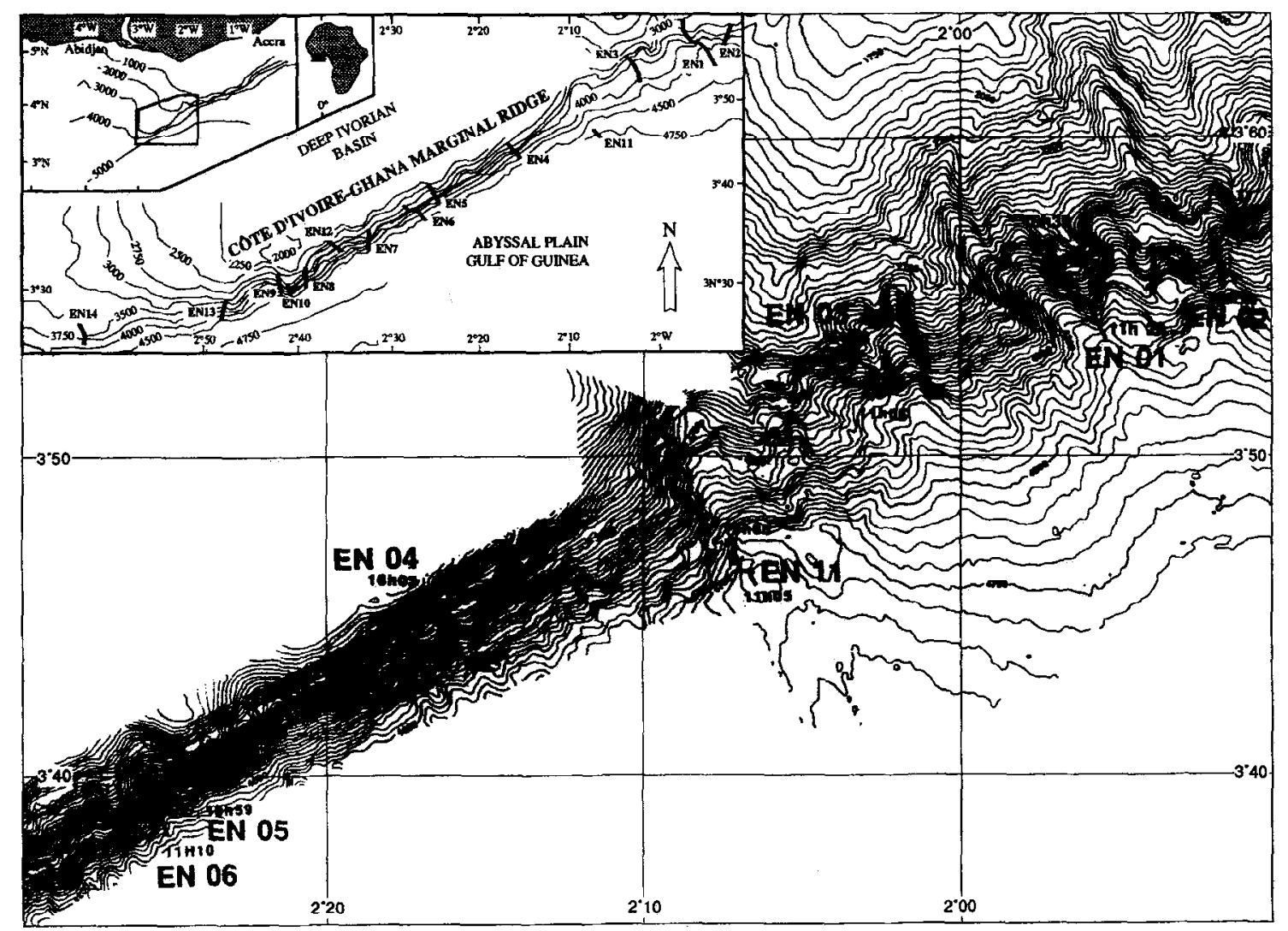

Figure 3

Location of Equanaute deep dives along the eastern and central domains of the Côte d'Ivoire-Ghana Marginal Ridge. The dives were performed between $4600 \mathrm{~m}$ and $2500 \mathrm{~m}$ water depth. About 5 to $6 \mathrm{~km}$ of seu floor was visited and $12 \mathrm{to} 15 \mathrm{in}$ situ rock samples were retrieved dur ing each dive.

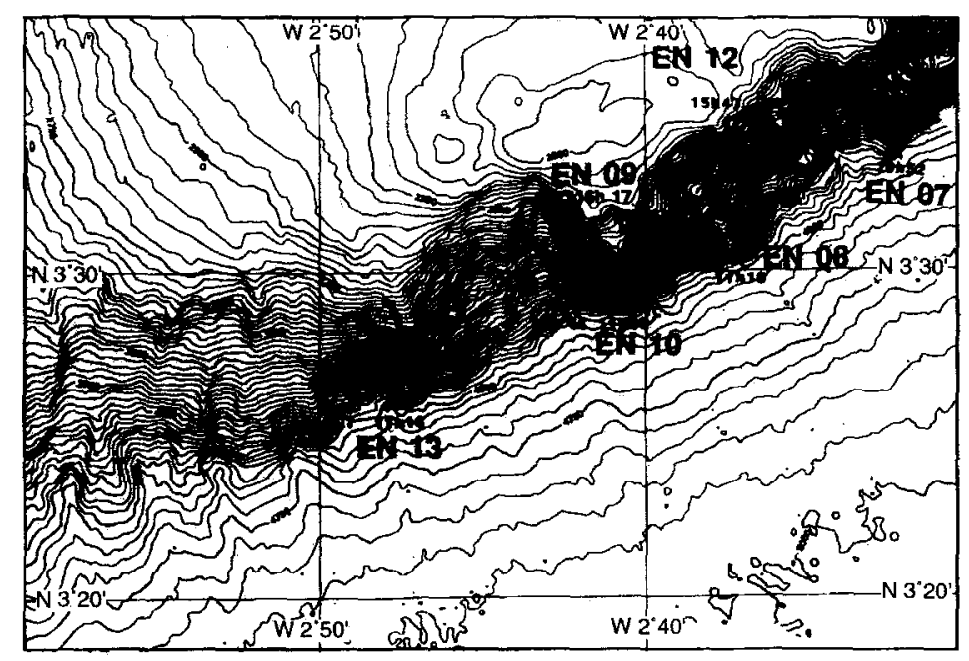

Figure 4

Location of Equanaute dives along the southwestern domain of the CIGMR. The dives were performed between $4300 \mathrm{~m}$ and $2250 m$ water depth.

dives EN07 to EN10 and dive EN12 have documented, near the slope foot, huge rocky chaos (made of blocks several metres to tens of metres in size) and, upslope, impressive vertical cliffs; (d) Lastly, Equanaute dives EN13 (Fig. 4) and EN14 (insert Fig. 3) visited the CIGMR south-western corner, where the average slope is less accentuated $\left(20^{\circ}\right)$, due to an increasingly soft sediment thickness and to the progressive CIGMR deepening.

CIGMR seismic stratigraphy

Prior to the deep dives, the seismic stratigraphy of the CIGMR and surrounding areas was established on the 
basis of a dense set of single-channel and multichannel seismic (MCS) reflection data (Blarez, 1986; Mascle et al., 1988; Basile, 1990; Basile et al., 1993; Basile et al., 1996). The good resolution and short spacing of these lines permitted detailed analysis and mapping of the successive sedimentary records of the Deep Ivorian Basin and bordering CIGMR shoulders. More penetrative MCS lines have, in particular, demonstrated the CIGMR to be made up of a thick pile of deformed sediments, with interval velocities of the order of $3.6 \mathrm{~km} / \mathrm{s}$ (Basile $e t$ al., 1996; Lamarche et al., 1997). Such velocities imply a sedimentary thickness locally in excess of 3 to $4 \mathrm{~km}$, as also supported by wide-angle seismic data (Sage, 1994; Mascle et al., 1995). Beneath both the CIGMR and its northern bordering basin, several acoustic units have been distinguished (Fig. 5):

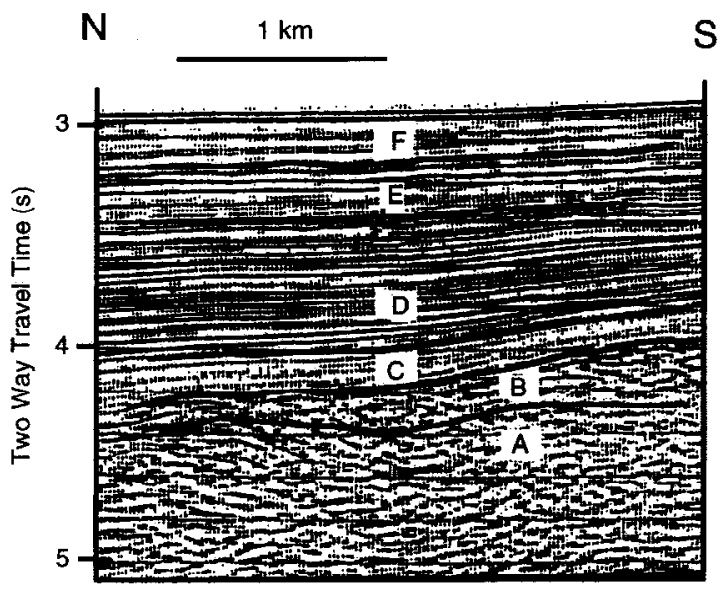

Figure 5

Main litho-acoustic units as defined by Basile et al. (1993) within the Deep Ivorian Basin and along the northern slope of the Marginal Ridge. ODP Leg 159 (Mascle et al., 1995) has allowed identification of these units as Early Cretaceous (B), Late Cretaceous to Paleocene $(C)$, Eocene $(D)$, Oligocene (E) and Miocene to Quaternary $(F)$ in age.

(1) A basal unit, referred to as unit A, constitutes the synrift infilling of half-grabens detected beneath most of the deep extensional Ivorian Basin; unit A usually shows a contrasted and continuous acoustic facies but displays a chaotic and discontinuous acoustic character nearby and within the CIGMR. Apparently directly exposed along the ridge southern slope, this formation is believed to constitute most of the ridge sedimentary pile. MCS profiles across the CIGMR indicate that this unit can be subdivided into three subunits (A0, A1, A2) bounded by successive unconformities (Lamarche et al., 1997).

(2) In the Deep Ivorian Basin, an overlying and unconformable unit B represents the first post-rift sedimentary cover (Fig. 7a). Along the ridge top, this unit may locally thicken considerably. Unit $\mathrm{B}$, being postrift in the extensional domain and clcarly deformed in the vicinity of the marginal transform ridge, has been referred to a "syntransform" unit, coeval with the CIGMR main transform tectonic stage (Basile et al., 1993). Recently Leg
ODP 159 has demonstrated the clastic nature of this unit and provided an Albian age for its upper section (Mascle, Lohmann, Clift et al., 1996).

(3) The overlying units $C$ to $F$, respectively of Late Cretaceous, Paleogene, Neogene and Miocene to Quaternary age (Mascle, Lohmann, Clift et al., 1996), are only affected by gravitational sliding and/or differential compaction deformations within the Ivorian Basin. They are either onlapping the ridge slope (units $C$ and $D$ ) or directly the ridge crest (units $\mathrm{E}$ and $\mathrm{F}$ ). Their respective arrangement is thought to reflect various CIGMR vertical movements (uplift and subsidence) throughout time.

\section{Tectonics}

Within the Decp Ivorian Basin, extensional features such as half-grabens and asymmetric horsts are well imaged on MCS lines. Tilted blocks are 4-5 km wide (Sage, 1994; Basile et al., 1996), comparable to those described in many divergent margin segments. The CIGMR is itself characterized by wrench tectonics with variable alongstrike deformations. Near its connection with the Ghanaian platform, the transform zone is expressed by reverse faulting and associated en echelon gentle folds (Fig. 6, $7 b$ ). From $2^{\circ} 10^{\prime} \mathrm{W}$ to $3^{\circ} 15^{\prime} \mathrm{W}$, the structural ridge is expressed by a $N 65^{\circ}$ trending acoustic basement-like high, which progressively deepens and shifts towards an eastwest direction. MCS data also clearly demonstrates that the CIGMR is cut in a series of extensional rotated blocks quite similar to those of the neighbouring northern Ivorian basin (Basile et al., 1996; Lamarche et al., 1997) (Fig. 7c). Wrench-fault lineaments are less easy to detect since they were probably activated as sub-vertical features crosscutting clastic, and already deformed materials (Basile et al., 1989; Popoff et al., 1989) (Fig. 6). However, MCS line MT01 (Fig. 7d) shows that near its western end, the fossil transform is still expressed as a buried, $10 \mathrm{~km}$ wide complex flower-type structure. Finally, west of $3^{\circ} 10^{\prime} \mathrm{W}$, close to the oceanic abyssal plain, the marginal ridge vanishes and passes to a series of en echelon minor ridges, some $10-15 \mathrm{~km}$ in length, a few kilometres wide and less than $500 \mathrm{~m}$ in elevation. Further west, these almond-shaped bodies connect with aligned acoustic basement highs which denote the fossil Romanche Fracture Zone (Fig. 6).

\section{Lithology and dating}

Before the Equanaute dives, very few samples were recovered along the transform margin southern slope by piston coring or dredging (Blarez et al., 1987). All consisted of sandstone or siltstone, with the exception of a few quartzites assumed to be of Paleozoic age (Mascle and Smit, 1974) and a black shale-type claystone. None of these samples could be correlated with the different seismic units. However, calcareous sandstones, presumably pertaining to A or B units, yielded an ostracod fauna of latc Albian agc (Grosdidier, oral comm.), while a piston core, retrieved from the CIGMR top, indicated a middle Albian shallow marine environment (Klingebiel, 1976). Recent ODP drilling operations have shown that most of 


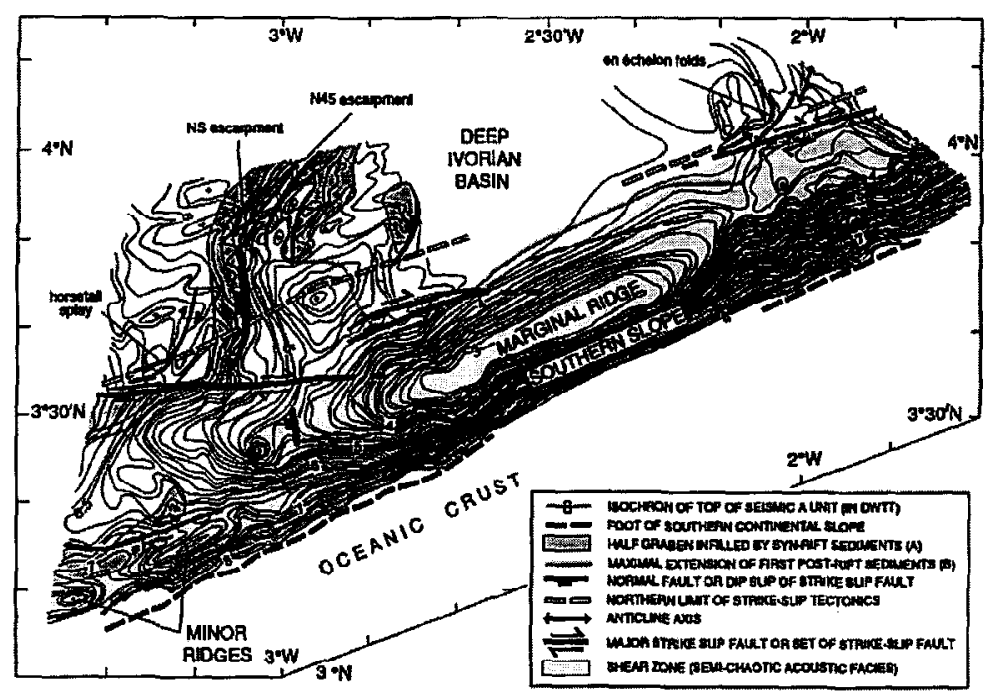

Figure 6

Structural sketch of the Côte d'Ivoire Marginal Ridge and surrounding areas (modified after Basile et al., 1993). Depth is given in two-way travel time (seconds) to the top of the deformed sediments (units $A$ and $B$ ).

the CIGMR consists of early Cretaceous clastics (lacustrine to prodeltaic sediments), covered unconformably by thin late Cretaceous open marine sediments and condensed Cenozoic deposits (Mascle et al., 1996).

\section{DEEP DIVE RESULTS}

Deep dives show that a sedimentary section is almost continuously exposed along the CIGMR southern slope.

E

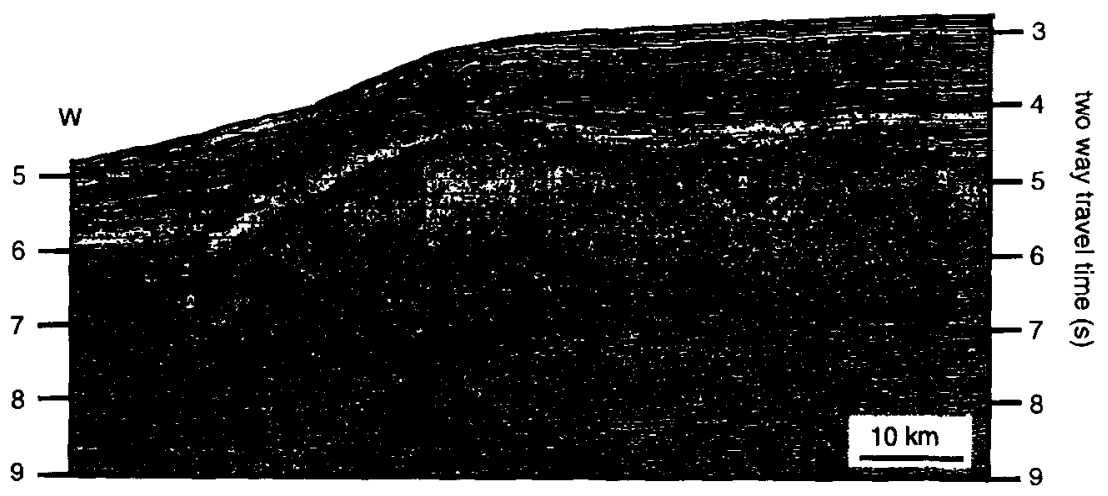

Figure $7 a$

Example of an east-west MCS migrated section across the Deep Ivorian Basin. The section shows a series of rotated blocks bounding half-grabens infilled by the $A$ unit. The break-up unconformity is located between units $A$ and $B$.

NNW Line MT03

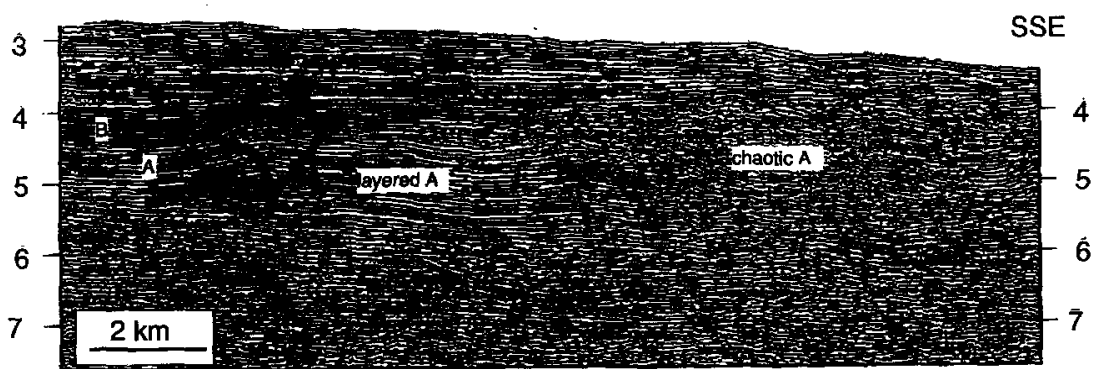

Figure $7 b$

Example of a migrated MCS section across the eastern transform domain nearby its contact with the Ghanaian Platform. Note the reverse faulting which has deformed the lower units within the proximal Ivorian Basin. 
Figure $7 c$

Example of a migrated section over the ridge top. The section illustrates a rotated block and its bordering half graben. Unit A infills the graben, and is covered unconformably by the unit $B$, itself onlapped by post-tectonic sedimentary sequences.
Figure $7 d$

Example of a migrated MCS section across the westernmost and buried extension of the Marginal Ridge. The western termination of the ridge appears deformed in a set of positive flower structures. Southward, a minor ridge is emplaced near the continent-ocean boundary.

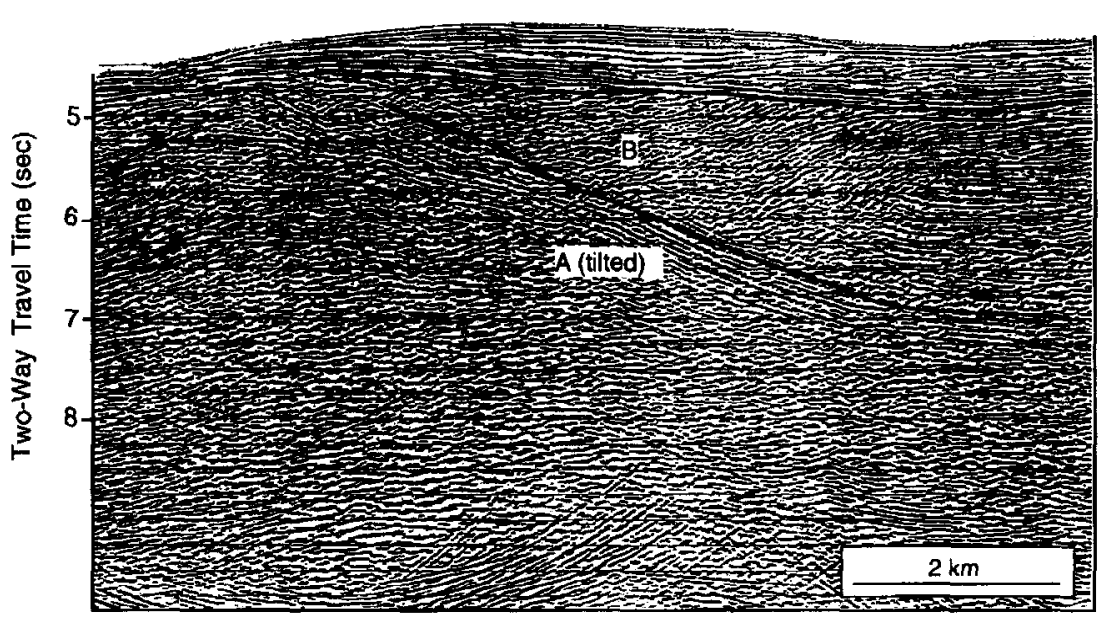

NNW

SSE

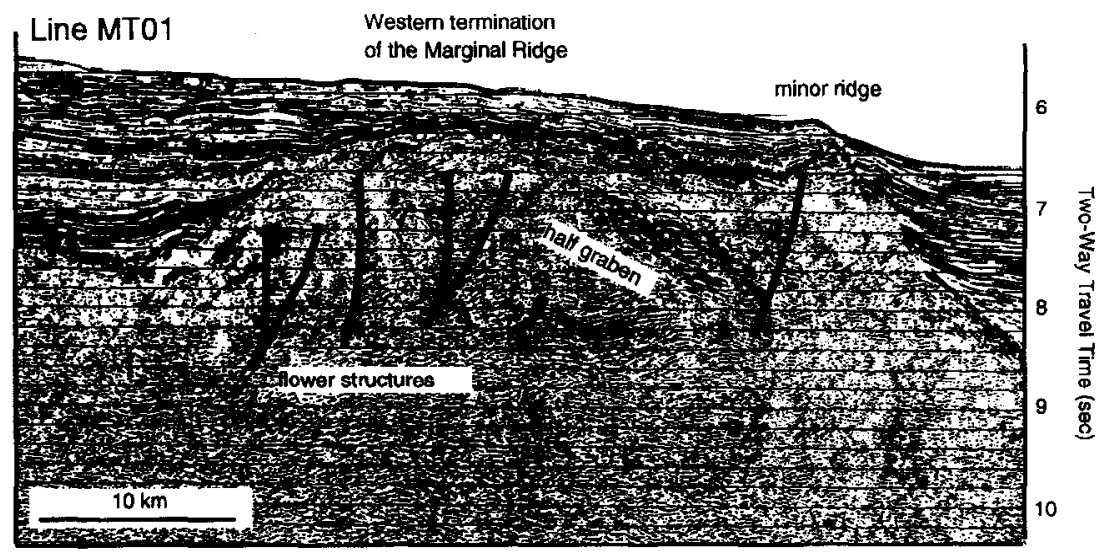

Its lithology and structure have been well characterized by direct observations, continuous video records and over 2000 colour photographs, as well as by analyses of handsized polished slabs and thin sections made on most of the 165 retrieved samples. Dating still remains difficult since the recovered sediments were found almost barren of microfossils (see below).

\section{LITHOLOGY AND AGE OF THE CIGMR SEDIMEN- 'IARY SECTION}

\section{Lithofacies}

A lithofacies reconstruction was attempted by Guiraud et al. (1997a), combining studies of in situ outcrop attitudes and rock sample observations from several selected representative dives. Direct in situ observations and video records from most of the other dives have, however, been taken into account to determine distinct morphological features, clearly related to three major lithofacies (Mascle et al., 1993). We have thus attempted: (a) to establish an accurate lithology of exposed rocks for each different slope domain; (b) to characterize the main lithofacies associations; (c) to better assess the paleoenvironmental conditions coeval with the successive tectonic stages of the CIGMR formation.

For the northeastern CIGMR domain, we selected dives EN01 and EN11 (Fig. 4), whereas the central and southwestern areas were analysed using dives EN04 to EN06 and dives EN12 to EN14 respectively (Figs. 3, 4). In all dives, the slopes consist of alternative gentle benches, mud and scree draped or encrusted, interrupted by $40-80^{\circ}$ steep scarps. Thinly laminated dark or yellowish finegrained rocks (claystones), which represent Facies 1, are occasionally exposed along these benches. The numerous outcrops along the steep scarps reveal three other lithofacies. Facies 2 is expressed by $5-40 \mathrm{~m}$ high walls (Plate I) including medium-scale trough cross-beds, 0.2-2 $\mathrm{m}$ thick. The highly fractured scarps formed by Facies 3 


\section{Morphological features and inferred lithology}

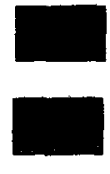

Facies 1 Mud draped or 4: ledge (clay or silt?)
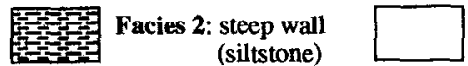
encrusted substrate

Facies 1' or 4: clay (siltstone) (unspecified facies)

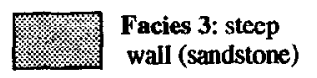

$$
\begin{aligned}
& \text { S. } 6 \rightarrow \text { Sampling } \\
& -- \text { FZ Fault Zone }
\end{aligned}
$$

Sedimentary structures revealed by submersible observations
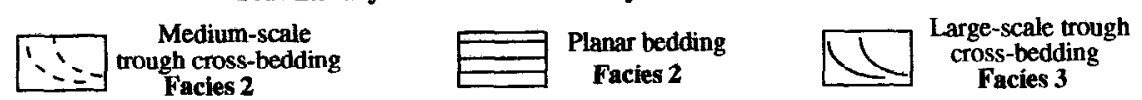

Sedimentary structures observed on rock samples
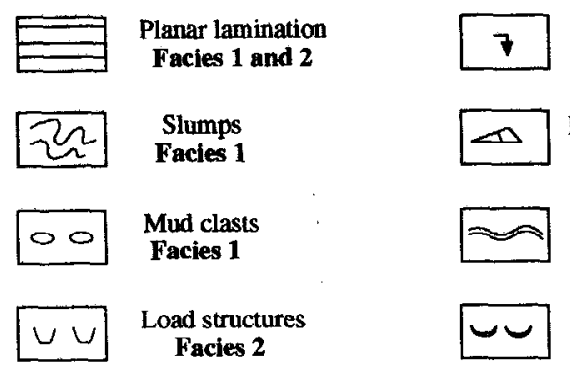

Bioturbation

Facies 2

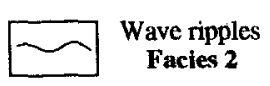

Lenticular bedding

Facies 2

Cross laminae

(current ripples)

Facies 2 and 3)

Wavy bedding

Facies 2

Cross strata

facies 3

Flaser bedding

Facies 2

Motuling

Facies 3

Figure $8 a$

Main symbols used for representation of clastic deposits of Figures $8 \mathrm{~b}, 9,10$.
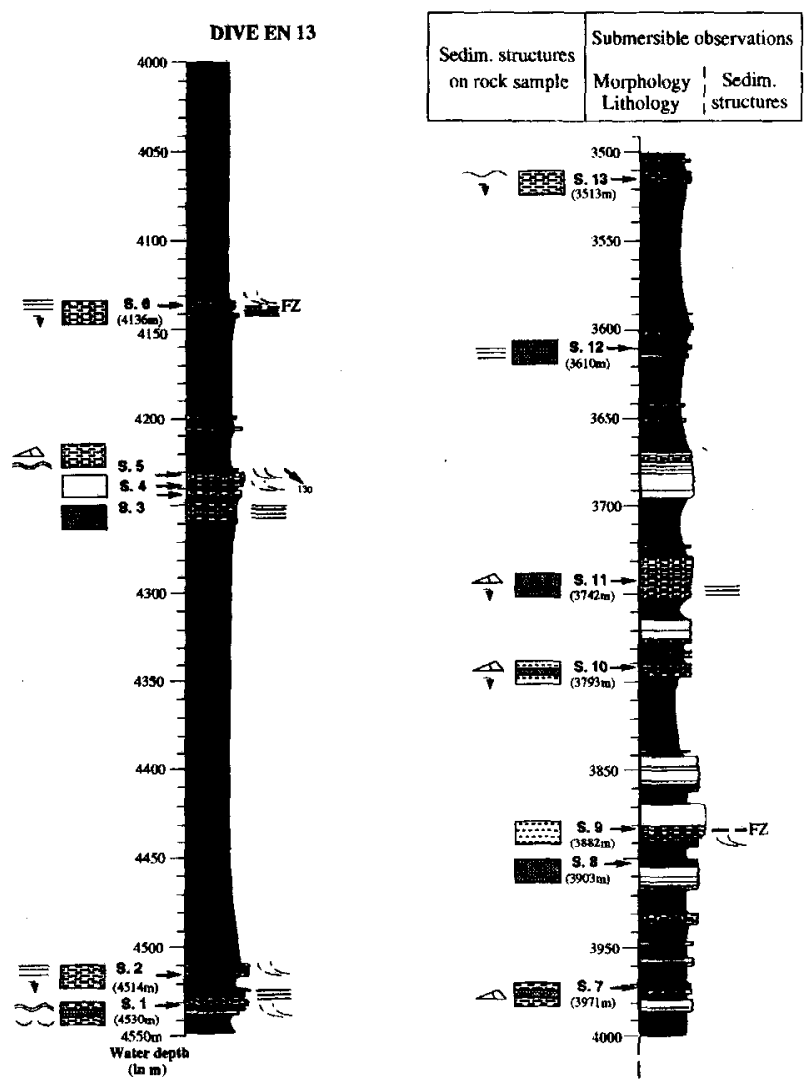

Figure $8 b$

Example of a lithologic log reconstructed from observations and sampling during dive EN13 (after Guiraud et al., 1997b); S1 to S13 refer to sample locations. 


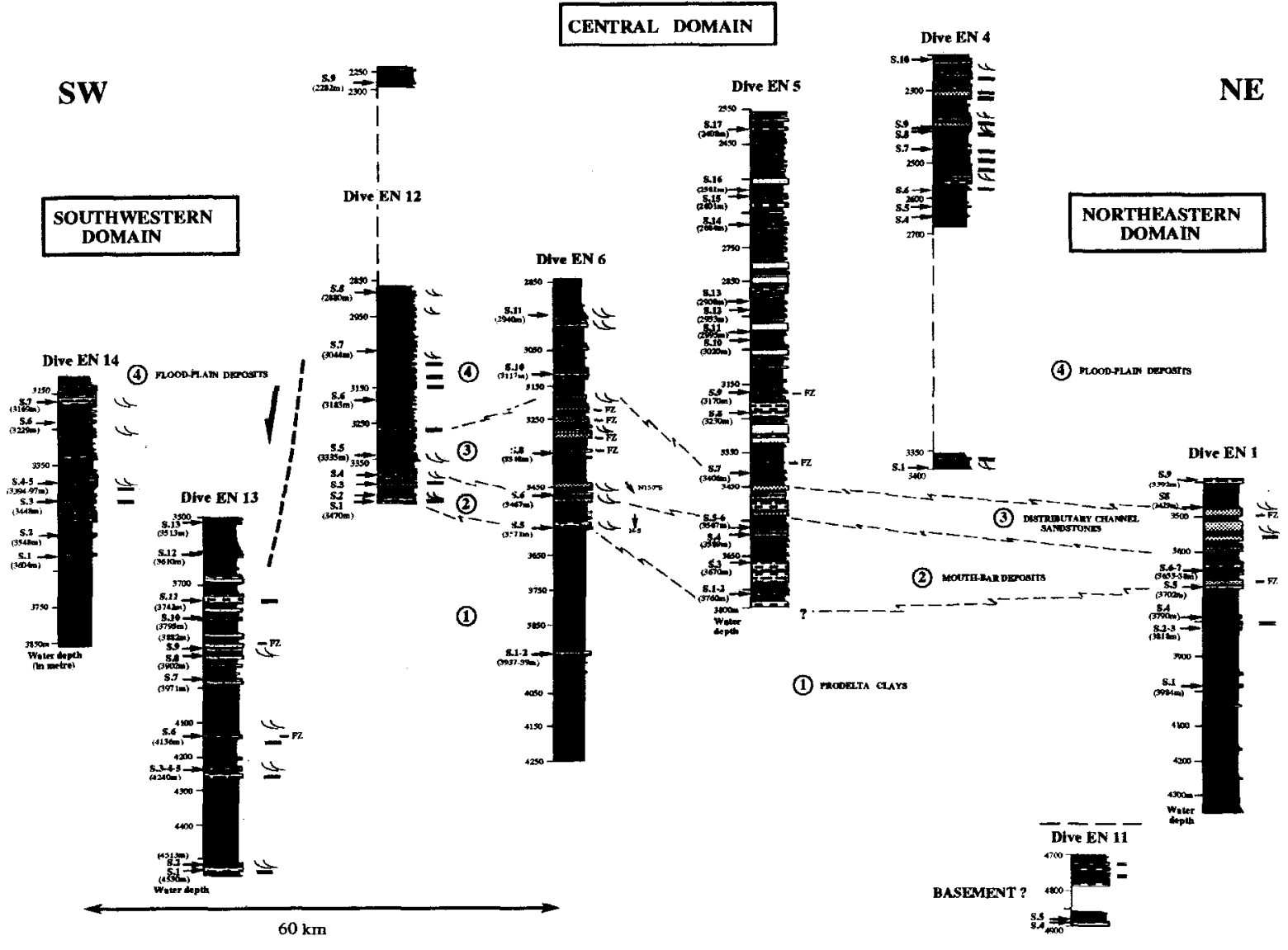

Figure 9

Reconstructed lithological logs of clastic sections (syn-rift to syn-transform deposits) both outcropping along the northeastern, central and southwestem CIGR domains (see location on Figs. 3, 4) 1, 2, 3, 4 refer respectively to sections where prodelta clays, mouth-bar deposits, distributary channel sandstones and flood plain deposits are respectively predominant. An attempt of correlation along the CIGMR slope is shown by dotted lines.

FACIES 4 FLOOD-PLAIN CLAYS

Figure 10

Synthetic sedimentary sequences of clastics exposed along the marginul ridge southem slope as deduced from integration of dive observations and in situ sampling.
MOUTH - BAR DEPOSITS

FACIES 2 (INTERBEDDED CLAYS SLLSTONES AND SANDSTONFS)

FACIES I PRODELTA ClAYS
DELTA PLAIN SEQUENCE

DELTA FRONT

AND

PRODELTA

SEQUENCE 


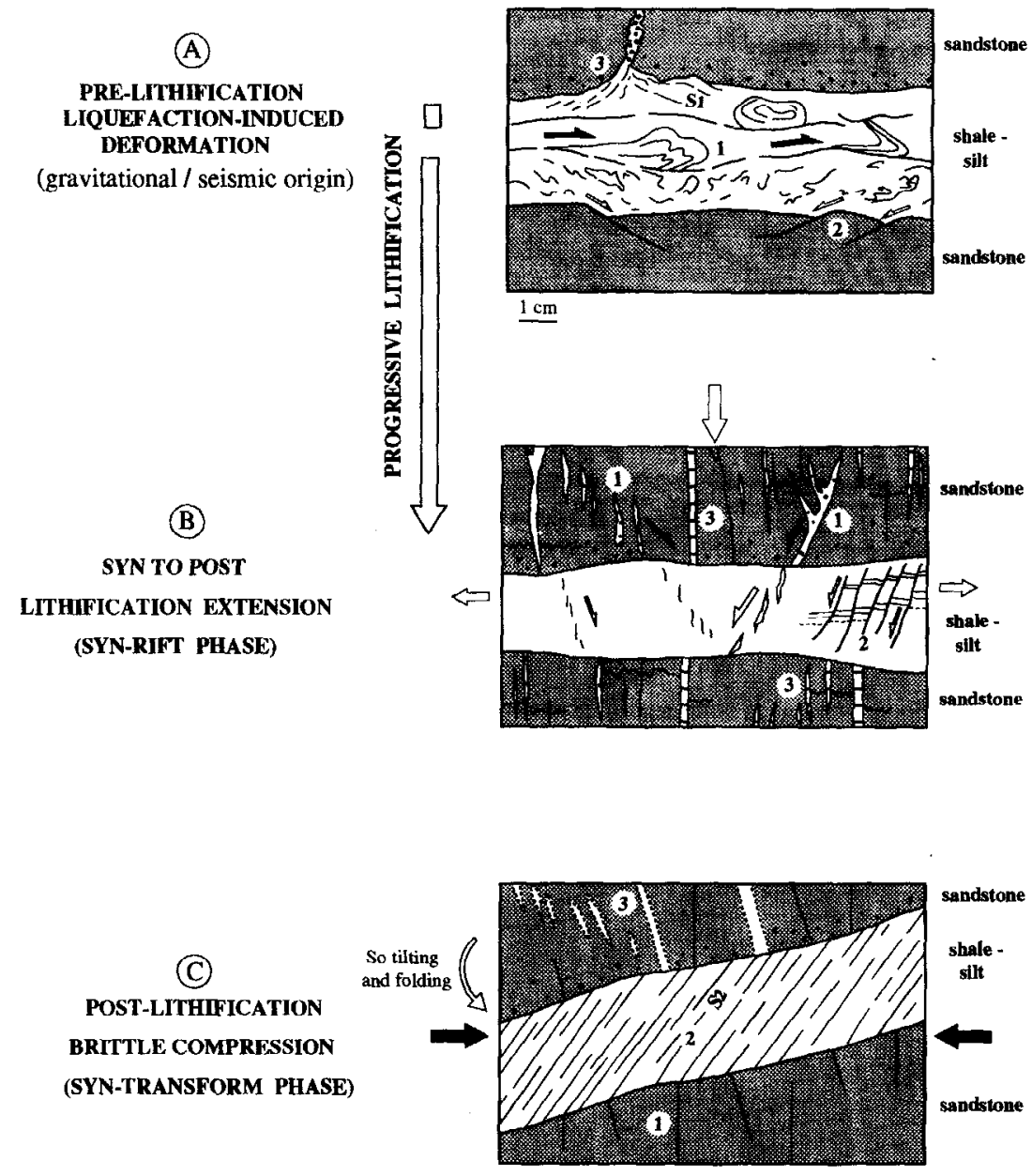

Figure 11

Summary of the deformational history of the CIGMR as observed on samples. The characteristic sediment sequence consists of laminnted siltstones and shale interbedded with sandstones and rare gravel casts.

A: Pre-lithification liquefaction-induced microstructures: type 1 - Tight to disharmonic isoclinal slump microfold and associated sliding bedding planes; type 2 - Listric normal microfaults; type 3-Mud pipe with fan-shaped hydroschistosity (SI).

Syn to post-lithification extensional microstructures: type 1 - syn-lithification normal to bedding quartz vein; type 2 - pervasive normal synlithification microfaults; type 3 - post-lithification normal to bedding quartz vein.

C: Late brittle wrench microstructures: type 1 - vertical britfle jnint; type 2-slaty cleavage S2; type 3 - tilted extensional microstructures.

vary from 10 to $40 \mathrm{~m}$ in elevation, and are generally in basal sharp contact. They show large-scale trough crossbedded sets (2-4 $\mathrm{m}$ thick) grading up into massive layers of about one metre in thickness (Plate I).

Almost all the recovered samples are of siliciclastic nature and belong to the same siltyclay-to-sandy formation. Facies analysis has been proposed on the basis of sedimentological critera (lithology, texture and biological microstructure) as shown in Figure $8 a$.

The few retrieved Facies 1 samples consist of black shales, dark organicmatter-rich clays and thinly-laminated bioturbated siltstones, generally affected by numerous synsedimentary deformations (see further). Locally, this facies may appear as massive outcrops, but it commonly displays diffuse parallel beds related to slight grainsize variations. $\Lambda$ carbonate claystone from dive EN01A indicates the local influence of a more open marine environment.

Facies 2 corresponds to wavy-bedded yellowish siltstones and claystones alternating with lenticular to flaser-bedded greenish fine-grained sandstones, frequently bioturbated. Subordinate components are well-sorted siltstones and finc-grained sandstones usually displaying prominant symmetrical ripples and parallel laminations.

Facies 3 includes yellowish, finc to coarse-grained feldspathic and micaceous graded sandstones. Thin microconglomeratic beds are observed over basal erosional surfaces. They grade up into poorly sorted to faintly cross- 


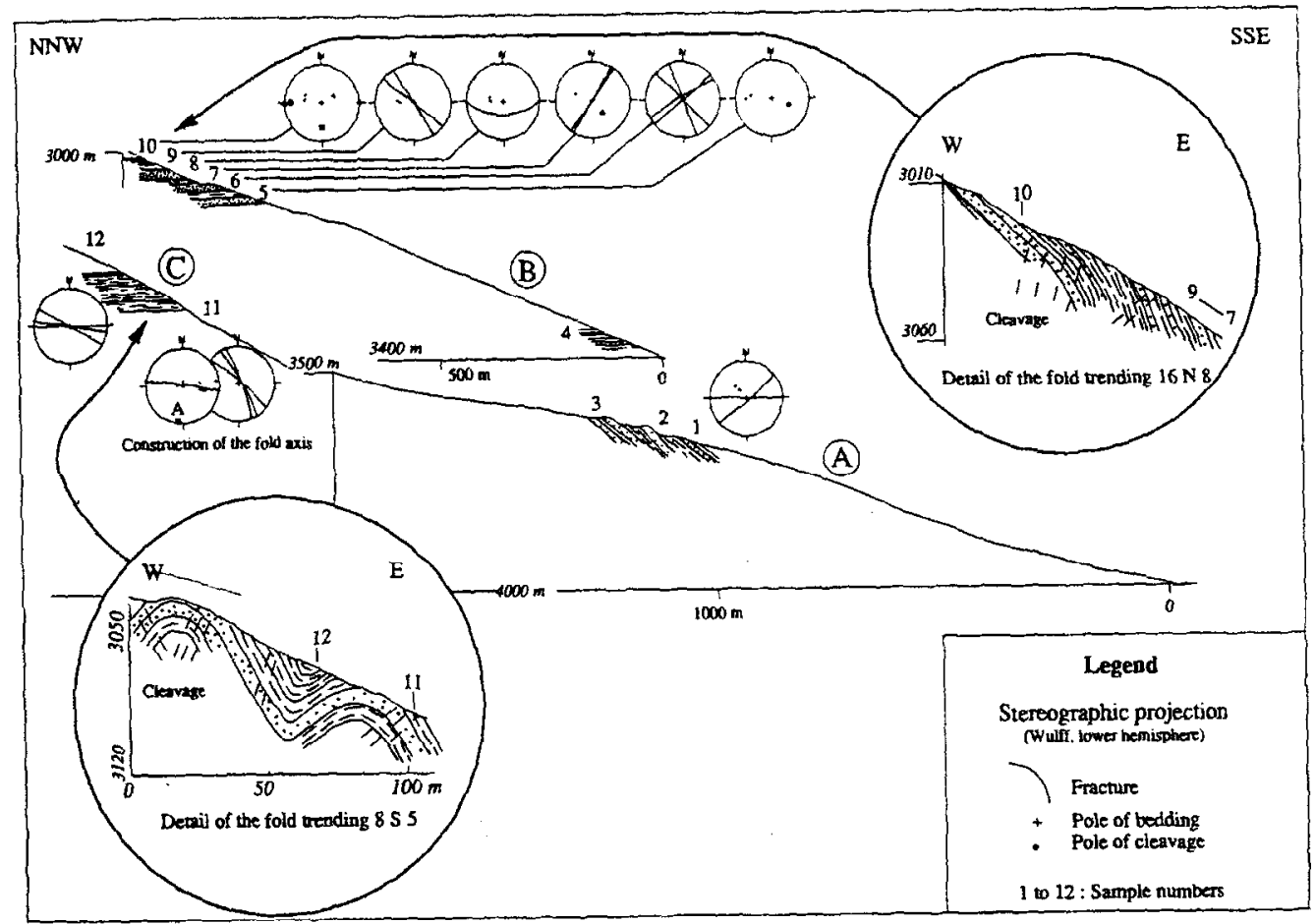

Figure $12 a$

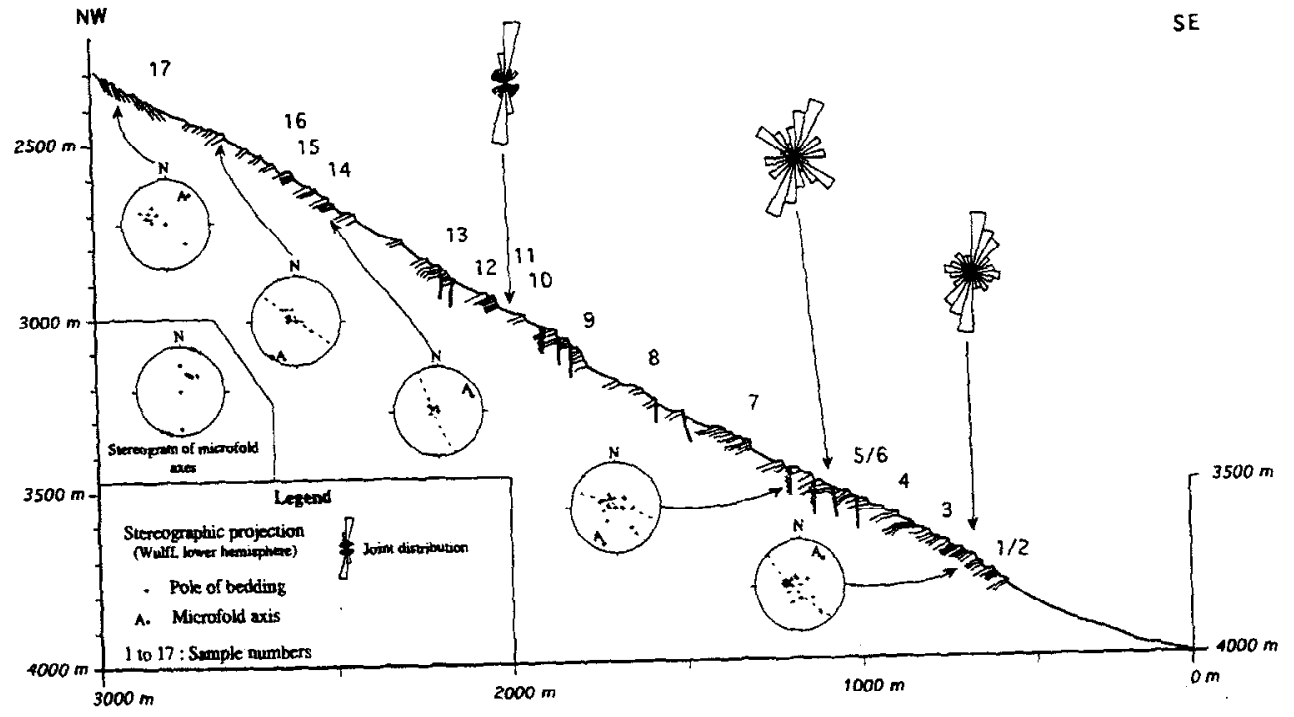

Figure $12 b$

bedded massive sandstones. A few greenish fine-grained sandstone beds display mottling structures and suggest subaerial exposure.

Finally, a Facies 4 corresponds to massive, mottled finegrained sandstone beds covered by yellowish siltstone layers, and thinly laminated and organic matter-rich claystones. These sandstones often show an upward decreases in cross-set thickness.

\section{Biostratigraphic and fission track dating}

Dating Equanaute retrieved samples remains an uutstanding problem, since the entire section appears almost barren of foraminifers and nannoplankton. Until now only very few samples, chiefly from dive ENO1 (Fig. 3), have yielded marine microfauna. A carbonate claystone from this dive indicates a time span between Barremian and 


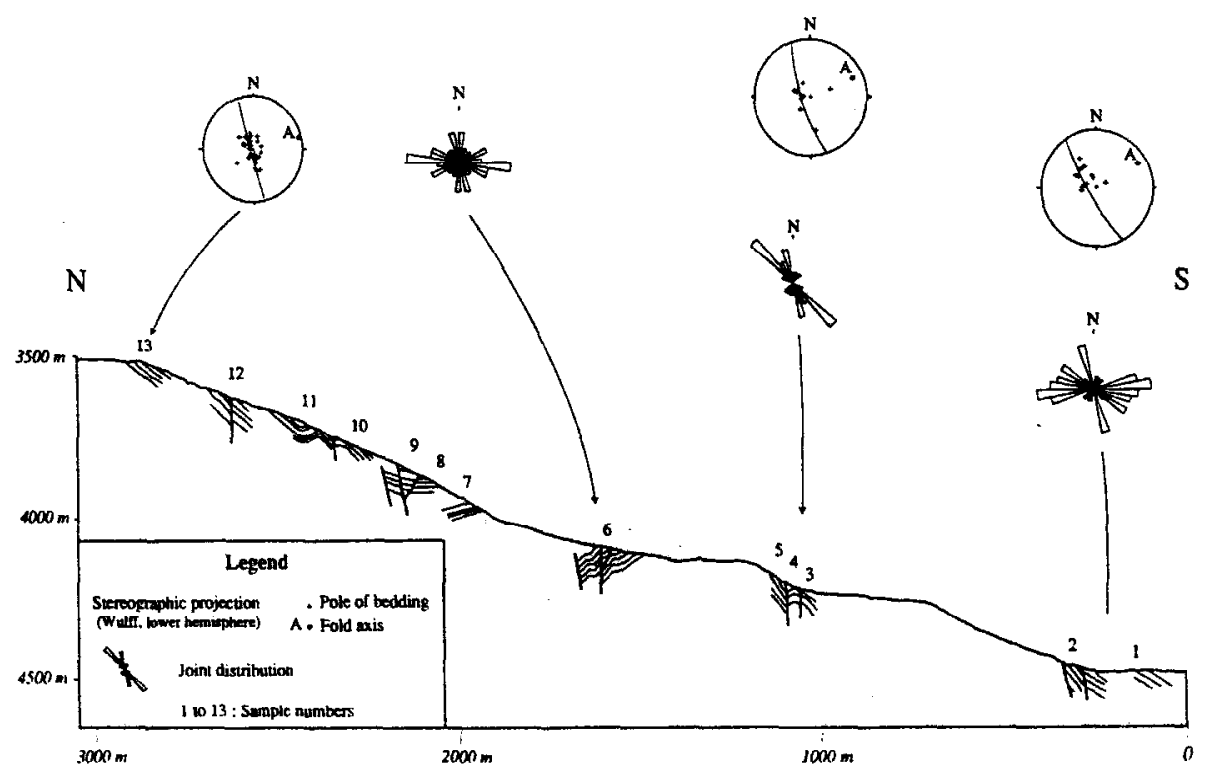

Figure $12 c$

Examples of synthesis of structural and microtectonic observations made during dives EN03 (Fig. 12a), EN05 (Fig. 12b) (location on Fig. 3) and ENI3 (Fig. 12c) (location on Fig. 4); stereographic projections of bedding planes (SO) and plotting of the joint directions on rose diagrams are shown.

early Cenomanian (more likely Albian) on the basis of tiny and poorly preserved planktonic foraminifers. Palynologic assemblage studies, still in progress, seem more promising. For example, the palynological analysis of sample 11 (from EN03 dive) has yielded a microflora shed by terrestrial plants. This assemblage is dominated by conifer pollen grains (genera Araucariacites and Classopollis), then by fern spores (genera Cicatricosisporites, Leptolepidites, and Dictyophyllidites). Genus Afropollis and species Elaterosporites verrucatus [Jardiné and Magloire, 1965] (Jardiné, 1967), permit us to assign an age between middle to late Albian to this sample (Jardiné, 1967). Dinoflagellate cysts are also noticeable: their occurrence confirms a marine influence during the deposition of sediments, whose palynological content clearly reveals a continental origin. A preliminary attempt has been made to date the sediments using fission track analysis on apatite and zircon minerals from coarse-grained sandstones (Bouillin et al., 1994). New data available from detrital apatites clearly indicates heating above $120^{\circ} \mathrm{C}$. The following ages have been obtained for cooling below the $60^{\circ} \mathrm{C}$ isotherm: 83 Ma (sample 8 dive EN01, $3479 \mathrm{~m}$ water depth); $69 \mathrm{Ma}$ (sample 9 dive EN04, $2405 \mathrm{~m}$ water depth); $68 \mathrm{Ma}$ (sample 5 dive EN06, $3571 \mathrm{~m}$ water depth); 78, 90 and $92 \mathrm{Ma}$ (dive EN09, at 2673, 3524 and $3905 \mathrm{~m}$ water depth respectively). These values tend to support two distinct thermal events; an older one, around $90 \mathrm{Ma}$, may be tentatively related to heating during intracontinental transform fault activity; a second one, between 70 to $80 \mathrm{Ma}$, may be correlated to heating by the passing the southern oceanic spreading centre, during the latest Cretaceous (Bouillin et al., 1997).

\section{Depositional environment}

Based on dive observations and sample lithofacies studies, the lithological log of dive EN13 (Fig. 8b) has been selected as an example to present and discuss the vertical facies relationships observed across most of the investigated sections. For this reconstruction, we assumed elementary scarp elevations to be representative of sedimentary unit thickness, since the rocks were only gently dipping. The resulting composite sedimentary section appears to be more than $1000 \mathrm{~m}$ thick and includes cycles of alternating Facies 1 and Facies 2 deposits. Whereas claystones (Facies 1) seem to contribute up to $80 \%$ of the lower section, siltstones (Facies 2) are prevailing on the upper slope, between $3990 \mathrm{~m}$ and $3670 \mathrm{~m}$ water depth. Facies 1 to 2 vertical associations show obvious thickening-upward sequences between depth intervals $4260-4230 \mathrm{~m}, 3890$ $3870 \mathrm{~m}, 3860-3840 \mathrm{~m}$ and $3740-3730 \mathrm{~m}$. Most of the samples from this area consist of bioturbated siltstones with lenticular to wavy and flaser bedding; the remnants are fine-grained sandstones.

The thickening and coarsening upward cycles, about $20-40 \mathrm{~m}$ thick, are characterized by a thick basal mudsilt member (Facies 1) progressively grading up into an intermediate silt-dominated member (Facies 2) (Fig. 10). We interpret such a basic sequence as a result of progradation of mouth-bar deposits (lenticular to wavybedded bioturbated siltstones and thin sandstones) onto thick black clayey-silty formations suggestive of prodelta deposits (Guiraud et al., 1997a). Locally, the upperlying siltstone beds may be truncated by 10 to $30 \mathrm{~m}$, upward thinning and fining, sequences where diffuse lag conglomerates and coarse, large-scale cross-bedding 
Plate I
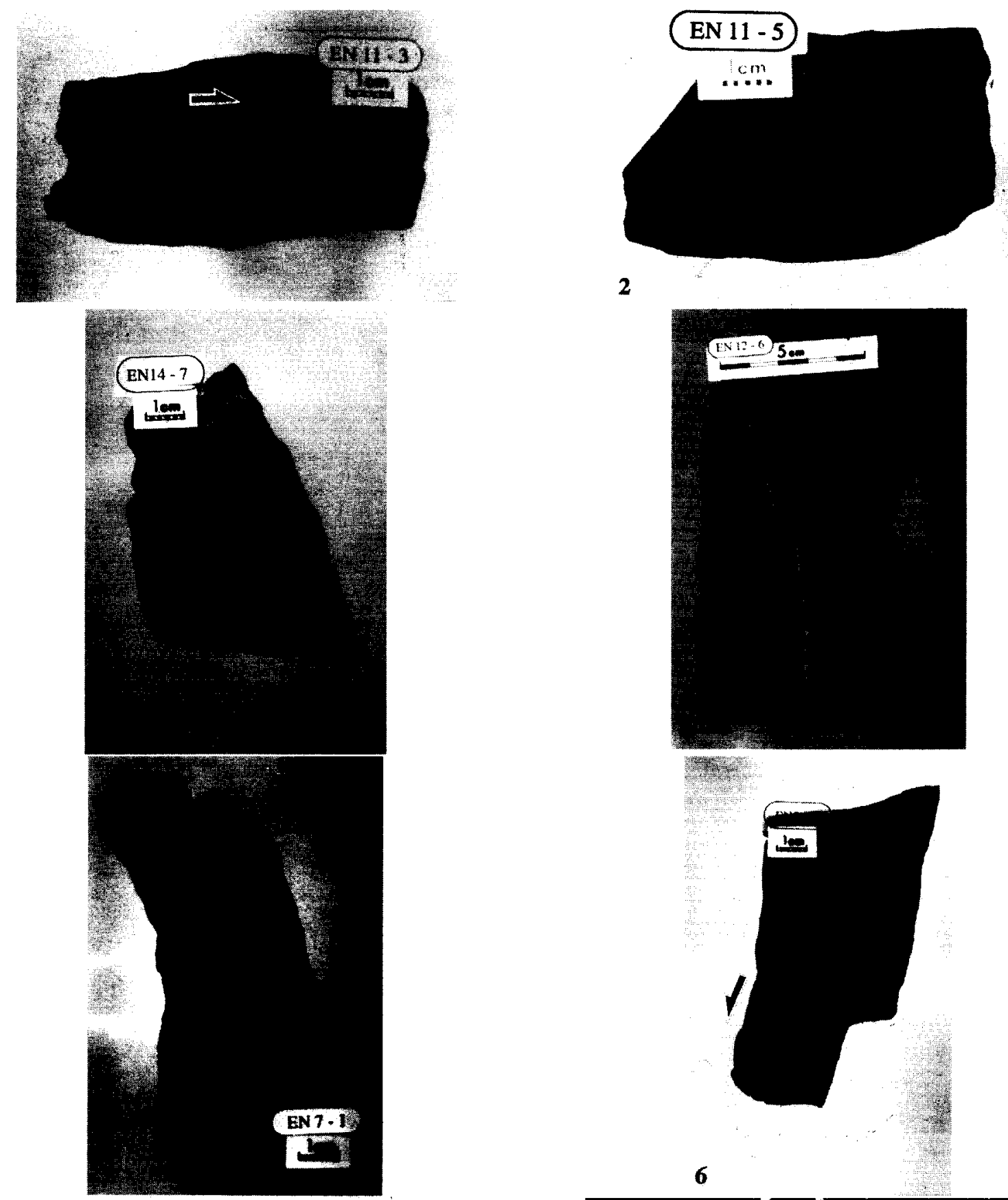

$\left(\operatorname{IrI}^{2}-6\right) 5$

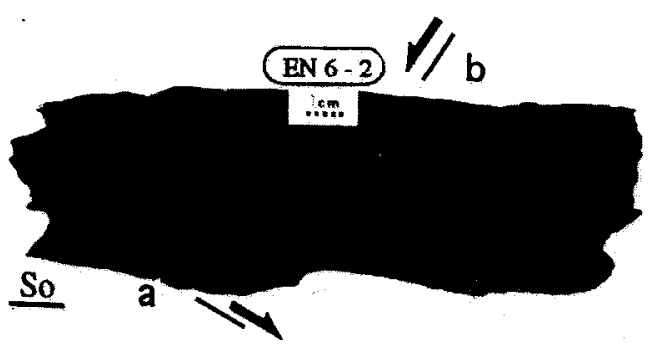

6

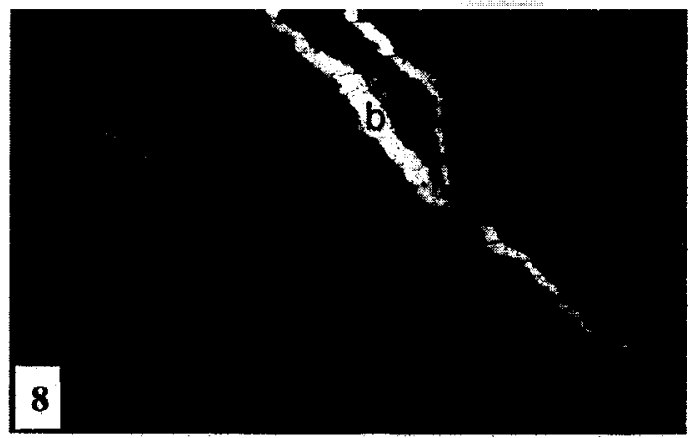


Plate II
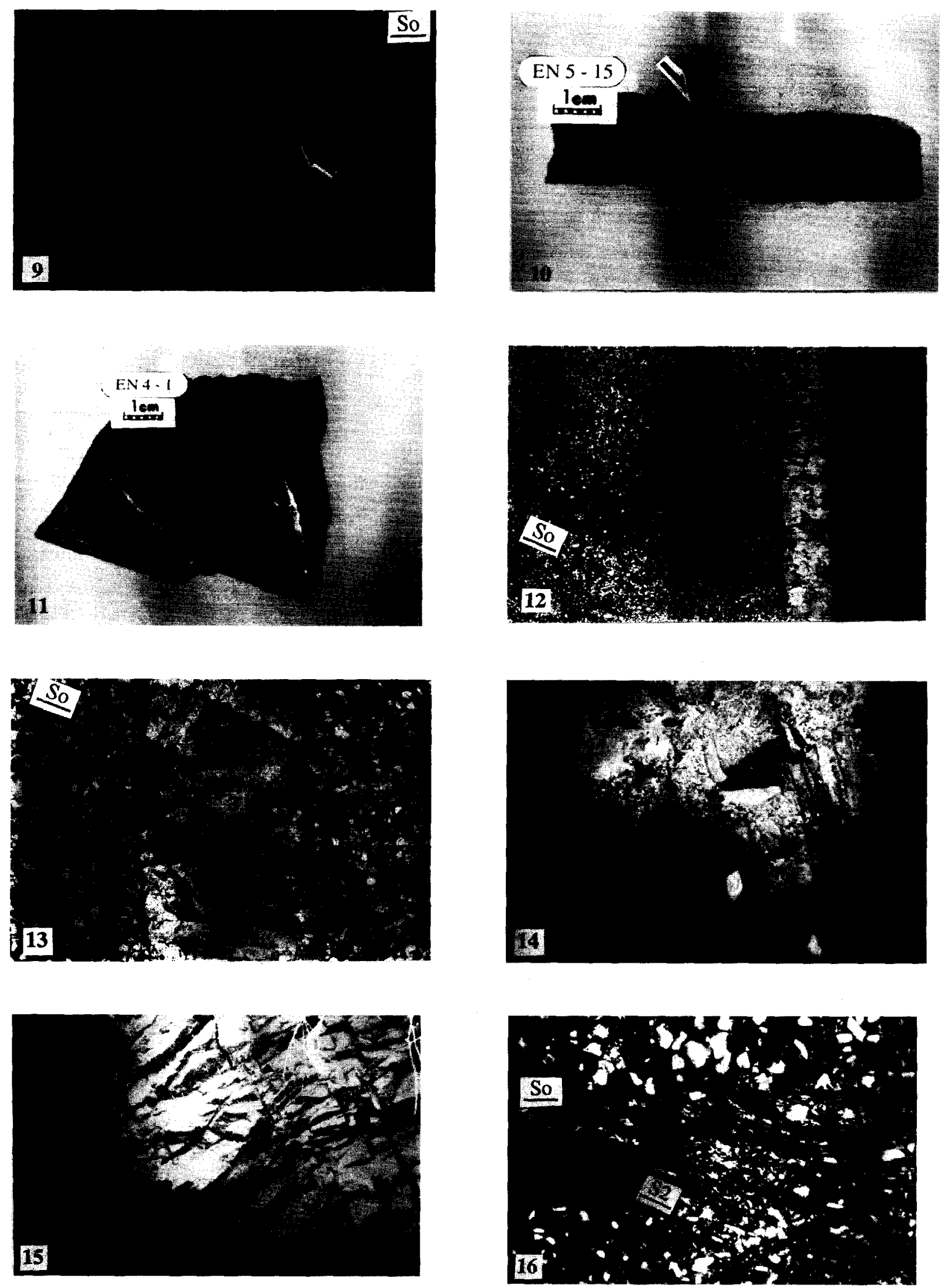
sandstones (Facies 3) are prevailing. These pass upward into Facies 4 sandstones, then siltstones and claystones. This second basic sequence, prevailing along the eastern CIGMR (dives EN01 to EN03), is interpreted as result of fluvial distributary channel activity and abandonment. The overlying claystones, rich in plant remains (Facies 4), may themselves be related to a flood-plain environment. Those cycles are believed to represent basic sedimentary sequences, deposited as a consequence of subsidence and sea-level fluctuations and/or a combination of both processes. The lithological sections reconstructed from the eight analysed dives characterize facies associations at the margin scale (Fig. 9).

The deepest dive (EN11), made at the slope foot below $4700 \mathrm{~m}$ near the eastern end of the ridge may have documented parts if the CIGMR basement. During this dive, black slaty shales and fine quartzites were sampled; they can tentatively be compared to Early Voltaian metasediments exposed along the Ghanaian coasts (Affaton et al., 1980). Above this potential basement, the overall sedimentary trend corresponds to a progressive upward transition from prodelta distal clays to more proximal facies such as mouth-bar deposits, distributary fluvial sandstones and flood-plain deposits. This trend, observed at a $50 \mathrm{~m}$ scale, also exists at the scale of the $2000 \mathrm{~m}$ thick sedimentary pile, where distal facies prevail at the base and are progressively replaced upward by more proximal facies. This succession implies a rather constant subsidence through time, which maintained a shallow water depth despite the deposition of more than $2000 \mathrm{~m}$ of sediments.

Horizontal correlations between dives remain hypothetical due to both the cyclic nature of the sedimentary log and the distance between each dive. For this attempt, each dive has been divided into several sections in which one of the different sedimentary facies ( 1 to 4 ) is prevailing. Accordingly, the correlations suggest that the central and northeastern CIGMR domains (Fig. 9) are tilted slightly northcastward. This may be the result of either synsedimentary or post-sedimentary movement of the entire ridge, or alternatively of differential subsidence, possibly triggered by transverse faulting. Within the southwestern ridge corner, dives EN13 and EN14 exhibit mainly Facies 4 sediments (flood-plain deposits), at depths greater than that observed during the dive EN12 (Fig. 12). Such a downward shift is likely to be due to normal faulting, as well evidenced nearby on seismic data (Fig. 7c) (Sage, 1994; Lamarche et al., 1997; Basile et al., 1996).

\section{CIGMR DEFORMATIONAL RECORDS}

Three successive deformation events are recorded within the indurated clastics exposed along the southern CIGMR slope. They relate respectively to pre-lithification and syn- to post-lithification extensional events and to a post-lithification (chiefly wrenching) stage. Our structural analysises has been conducted combining outcrop descriptions (from in situ, video observations and colour photographs), in situ measurements of bedding attitude, fault trends, brittle joints and fold axes, together with microstructure analyses performed on polished hand-sized samples and thin sections (Guiraud et al., 1997b); Benkhelil et al., 1997)

\section{Pre-lithification microstructures}

\section{Slumping}

Claystones exhibit a wide range of disharmonic and isoclinal microfolds (Plate I-1), including isolated recumbent microfolds with curvilinear hinges ( 1 on Fig. 11A; Plate I-2). Sharp thickening, thinning and boudinage of layers suggest ductile deformation mechanisms likely operative in unlithified and water-rich sediments. A few flat-lying microfolds show late, well-expressed and parallel to bedding mineral fabrics (Guiraud et al., 1997b). This demonstrates that compaction affected already slumped sediments.

\section{Microfaulting}

Slump microfolds are cross-cut by sliding bedding planes. Slickensided microfault planes are often glossy and show a typical metallic glint; they suggest hydroplastic microfaulting occurring in soft sediment (Guiraud and Seguret, 1987). All these features are specified as good evidence of pre-lithification and liquefaction-triggered microstructures, and are believed to reflect gravity-induced submarinc slumps within soft clays. They may possibly have been caused by seismic activity.

Pre-lithification deformations are also recorded by listric normal microfaults that dip some $30^{\circ}$ to bedding and root into bedding planes ( 2 on Fig. 11A; Plate 1-3). On thin sections, these features are only expressed by diffuse, $0.5 \mathrm{~mm}$ thick, zones showing particle redistributions. They may grade upwards into broken-up, chaotic entirely liquefied silty and clayey sediment. According to Ringrose (1988), similar liquefaction-induced microstructures may also be due to earthquake-triggered remobilization of water-rich sediments.

\section{Loadcasts and hydroschistosity $\left(S_{I}\right)$}

Finally, fine-grained sandstone and siltstone beds show frequent loadcasts and associated flames. The related mud pipes ( 3 on Fig. 11A), almost orthogonal to bedding, which were presumably acting as early dewatering pathways, exhibit a typical fan-shaped "hydroschistosity" pattern (S1 on Fig. 11A) (Benkhelil et al., 1997). In finely laminated siltstones, pencil-like parting fragments are frequently seen on outcrops. This specific pattern reflects a penetrative structure typical of a fracture cleavage. At a microscopic scale the siltstones show cleavage planes, best displayed in clay laminae, and passing to closely-spaced parallel fracture planes in sandy beds. Typical refractions are observed at interfaces between different grain-size lithologies; characteristic "horse tail" type figures, with iron-coated cleavage planes, develop at boundaries between sandstones and claystones.

All those soft sediment microstructures indicate a non-stable depositional environment where gravitational detachments and/or sedimentary remobilizations were probably triggered by seismic shocks. 


\section{Syn-lithification extension}

\section{Veining}

Among the extensional microstructures, two main sets of veins have been distinguished from their respective contacts and infilling, and their relative timing of emplacement (Guiraud et al., 1997b).

A first set of tensile quartz veins shows very indented contacts ( 1 on Fig. 11B; Plate I-4). On thin sections, the veins exhibit suture-like borders that closely follow, but do not truncate, the detrital quartz grains. Moreover, the vein infilling contains euhedral radial quartz and a few angular detrital grains, which are probable sediment remains mixed together with vein fluids during generation. The veins vary in attitude with sediment type. In claystones and siltstones, they appear as conjugated sets of potential normal fractures, together with associated en echelon quartz-filled veins; in sandstones the veins are generally normal to bedding. We believe that these firstgeneration veins originated from grain-to-grain separation mechanisms when the sedimentary matrix was weaker than the framework grains, i.e. during lithification. A few normal microfaults are associated with this veining ( 2 on Fig. 11B; Plate I-5 to 8 and Plate II-9 and 10). They are steep dipping $\left(50-60^{\circ}\right)$ with respect to the layering, and show offsets one millimetre to one centimetre in size. All these features substantiate a probable extension parallel to bedding when bedding was sub-horizontal. Moreover, in two in situ oriented samples (EN06-2, EN07-1), the faults, as well as the vein strike parallel to the north-south regional extensional faulting detected northwards within the rifted Ivorian Basin (Figs. 6, 7a) (Basile et al., 1993).

\section{Post-lithification deformations}

During most of the Equanaute dives, spectacular vertical cliffs of massive sandstones and siltstones (several tens of metres in elevation) were observed (Mascle et al., 1994). An intense fracturing, which resulted in very dense and regular brittle joint systems, has locally, chiefly in siltstones, created typical blocky outcrops. Both intense fracturing and jointing are in our opinion best explained by the effects of wrench-type tectonics, also well recorded, at minor scale by a set of cleavages and mineral recrystallizations (Benkhelil et al,, 1997). However, evidence of large-scale normal faulting and the occurrence of a second vein generation also indicate a post-diagenesis extensional activity.

\section{Veining}

A second generation set of extensional veins is filled with calcite or quartz crystals orthogonal to tension-gash walls in sharp contacts with the host rock ( 3 on Fig. 11B; Plate II-11 to 13). The sharp contacts, and the lack of inclusion, as well as the fibrous texture of this late veins strongly suggest that the material was quite cohesive during fracturation, i.e. that deformation occurred after lithification. Most of these late veins, appear normal to bedding. However, the sediments may be cut by branch curving veins, particularly in calcite-cemented sandstones. Associated stylolitic joints may occur along bedding planes. In this case, the stylolitic columns appear normal to sedimentary layering. This veining relates to extension parallel to bedding and has recorded both successive microcrack opening and subsequent instantaneous sealing (Ramsay, 1980).

\section{Brittle fracturing and faulting}

Brittle fracturing is the most conspicuous record of the postlithification deformations observed during dives (Benkhelil et al., 1997). It is particularly striking in fine-grained sandstones and siltstones, where it results in specific and regular patterns such as geometrically-cut planar slabs and/or cubic paving stones (Plate I). Brittle joints are well expressed ( 1 on Fig. 11C; Plate II-14): they locally form series of dense and narrow cleft sets where outcrops appear almost entirely crushed. Usually the joint average dip is quite steep and often sub-orthogonal to bedding; the joints appear preferentially distributed according to $\mathrm{N} 10^{\circ} \mathrm{E}, \mathrm{N} 45^{\circ} \mathrm{E}, \mathrm{N} 100^{\circ} \mathrm{E}$ and $\mathrm{N} 145^{\circ} \mathrm{E}$ trends.

During dives EN06 and EN07, the observation of planar and crust-coated surfaces a few square metres wide strongly suggests fault scarp planes; sudden dip variations, as well as local increase of fracturing and brittle joints are also suggestive of nearby fault corridors. Brittle faulting is also evidenced at sample scale by sets of normal micro faults, particularly well expressed in fine-grained sandstones and siltstones, where they appear as glossy and slickensided planes. Technical restrictions (narrow view field from the submersible) prevented direct in situ observation of largescale faults; these are, however, strongly suggested by local deep cuts and sharp cliffs seen within massive outcrops. Most of these features are believed to reflect extensional faulting, as also supported by seismic profiling.

\section{Folding}

Most of the dives allowed observation of frequent bed dip variations, indicative either of faulting or folding (Fig. 12). Direct evidence of folds was, however, virtually prevented by an in situ limited view field. Most of the folds have thus been deduced from careful dip measurements and bedding pole computations on stereonet projections. For example, two upright folds have been reconstructed, upslope between $3100 \mathrm{~m}$ and $3000 \mathrm{~m}$, near dive EN03 end (Bouillin, in Mascle et al., 1994) (Fig. 12a). Both folds, about $50 \mathrm{~m}$ in spacing, correspond to narrow, symmetric anticlines showing an axial fracture cleavage. Interestingly, a second investigation, made some $300 \mathrm{~m}$ west of the previous Nautile track, indicates a comparable folded structure. Similarly, dives EN05, EN06 and EN13 permitted observation of a series of narrow folds trending $\mathrm{N}-\mathrm{S}$ to $\mathrm{N} 10^{\circ} \mathrm{E}$ and $\mathrm{N} 110^{\circ} \mathrm{E}$ (Guiraud, in Mascle $e t$ al., 1994). Dives EN02, EN07, EN08 and EN12 also exhibit clear folding evidence, preferentially concentrated upslope (Plate II-15). Small-scale folding has, from place 
to place, been observed. The best example of in situ observed folding has been provided hy dive EN05, at a water depth of $3165 \mathrm{~m}$. There, a small fold, some metres in length and about one metre high, progressively vanishing upsection, shows a north-east dipping axis; it is interpreted as a probable drag fold generated in a strike-slip regime (Bcnkhelil et al., 1997).

Folding may also be expressed by very gentle, small-scale folds well recorded within thinly layered sandstones. This has often induced bedding-parallel slips now imprinted on sample bed planes as slikensides.

Most of the folded stuctures trend within north-south to north-east directions, and are seen to concentrate in the upper slope domain (Mascle et al., 1993). Such an observation is in good agreement with the occurrence of drag folds and the apparent concentration of wrench faulting features across the ridge top and bordering the upper slope, as evidenced on seismic reflection data (Basile et al., 1993; Basile et al., 1997).

\section{Cleavages $\left(S_{2}\right)$}

The dominant cleavage $S_{2}$ is recorded either as discontinuous plane sets or as narrow compact strips (Plate II-16). The cleavage planes bear syngenetic mica flakes, and evidence of displacement is attested by detrital grain dragging. This cleavage is believed to reflect a shear component during the deformation process (Benkhelil et al., 1997). The $S_{2}$ cleavage, detected along most of the entire continental slope segment, intersects an earlier, poorly imprinted cleavage $\left(S_{1}\right)$. On thin sections, braided, almond-like figures have been observed resulting from the intersection, at low angle, of the two $S_{1}$ and $S_{2}$ cleavages planes, while high angle intersections are emphasized by recrystallized mica flakes. Cleavage attitude measurements made in situ, and performed on a few oriented samples, are coherent and indicate an average direction close to $\mathrm{N}$ $50^{\circ} \mathrm{E}$, identical to the fold axis mean direction (see above); this strongly suggests a common origin.

\section{Low-grade thermal transformations}

The general greenish color of most of the retrieved samples testifies, at first, that low-grade thermal metamorphism has been once operative within the sedimentary section (Benkhelil et al., 1997). Clayey and silty formations have best recorded the mineral imprints of such thermal events attested, on thin sections, by microflakes of illite, chlorite and biotite, all being recrystallized along cleavage planes. An early similar mineral assemblage is present in the sediments, but is intersected by $S_{2}$ cleavage.

Chloritic stacks, including, here and there, interlayered muscovite fiakes, are occasionally seen in claystone and siltstone samples. These stacks, rarely observed in sandstones, are known to be indicative of very low-grade transformations (Craig et al., 1982). A similar early thermal event has been documented, further east of the studied area, in the lower Benue trough (Nigeria), which was characterized, at the same time span, by a rather comparable sedimentary and tectonic evolution (Benkhelil, 1988).

\section{DISCUSSION}

From the scismic reflection data set recorded prior to scientific dives, and according to experimental modelling of the deformations at the rift-transform intersection, Basile et al. (1992, 1993) have proposed a four-stage tectonic evolution of the Côte d'Ivoire-Ghana Transform Margin. This tectonic model, which may account for other transform margin segments, includes: rifting, continental transform, continent-ocean transform and, finally, passive margin stages.

RIFTING. According to available seismic data (seismic stratigraphy and structure; see above) during an early extensional stage, the continental crust of the future Deep Ivorian Basin started to stretch as a consequence of rifting between Equatorial West Africa and northeast Brazil, in early Cretaceous times. This resulted in the creation of a series of north-south half-grabens and associated rotated blocks such as those illustrated on Figure $7 a$. The coeval synrift unit was deposited with thickness in excess of $3 \mathrm{~km}$ in some grabens over the whole thinning basin, including along its southern border (the future CIGMR domain), where tilted horsts and accompanying half grabens were also generated (Fig. $7 c$ ).

Equanaute dive observations and geological samples demonstrate that the sedimentation was then terrigenous in the future CIGMR domain. The steep CIGMR southern slope effectively corresponds to a clastic succession, at least $2200 \mathrm{~m}$ thick, in which three major lithofacies are identified: (a) dark, organic-matter rich claystones; (b) laminated siltstones, and interbedded fine-gtained sandstones; (c) grey coarse sandstones and microconglomerates. These sediments were in all likelihood accumulated within a shallow marine environment of deltaic type, sometimes submitted to open marine influence. Some of them were even deposited in a probable sub-aerial setting, as evidenced by the recovery of thinly-laminated sediments attributed to lake deposits and scarce indications of sub-aerial exposures. Along the future transform ridge, the shallow detrital sedimentation, dating from early Cretaceous time (at least Albian), was probably directly influenced by the vicinity of the Brazilian continental shelf, as attested by its dominantly shallow depositional environment characteristics and the occurrence of thick progradational wedges detected on multichannel seismic data across the eastern CIGMR (Lamarche et al., 1997). Microstructural analysis of the samples also clearly substantiates that the clastics were deposited on a tectonically unstable platform submitted to rapid subsidence, gravity-induced slumping and faulting, and probable earthquake shocks. These conclusions are supported by an overall sediment thickness in excess of $3 \mathrm{~km}$ (according to refraction data), pre-lithification microfolds, hydroplastic shear fractures and other liquefaction-induced microstructures. Synlithification extensional microstructures (quartz veins and 
normal microfaults) may indicate incipient strike-slip related deformations, inferred as initiating along the southern Deep Ivorian Basin, i.e. within the future CIGMR domain, before the end of rifting. Their apparent northsouth strike, similar to the general trend of the divergent basin extensional blocks, suggests, however, that extension persisted during sedimentary lithification.

CONTINENTAL TRANSFORM. Rifting ceased in the Deep Ivorian Basin when the oceanic crust was created along its western edge. Continental break-up was then recorded in the area by a typical post-rift unconformity and by the deposition of seismic unit $B$ in wide asymmetric depocentres (Fig. 7a). Along the CIGMR domain, initiation of the drift stage induced wrench tectonics as a consequence of transform-type motion between the two parting continental plates. This stage also induced an increasing wrench deformation on the CIGMR itself. In the central and western CIGMR (the upper clastic section), locally truncated by conglomerates and cross-bedding sandstones may constitute a sedimentary record of this event. Isopach folding and related bedding-parallel slips (chiefly recorded within homogeneous shaly, silty or interbedded siltstone-sandstone formations), coeval slight flattening deformation (well attested by cleavage), and finally the dense fracturing (which has resulted in a remarkable slope shaping), are interpreted as tectonic identifications of such intracontinental wrenching activity. Moreover, dive obscrvations clearly attest that deformations arc increasing upslope. This observation is consistent with seismic reflection data which illustrate drag folds and branching wrench-related lineaments over the ridge top and adjacent sedimentary basin (Basile et al, 1993).

CONTINENTAL OCEAN TRANSFORM. Final continental parting between west Africa and northeast Brazil is helieved to have occurred in the area around Santonian times (Mascle et al., 1988; Basile et al., 1993). This event resulted in the establishment of tectonically active contacts between the newly created Gulf of Guinea oceanic crust and the continental CIGMR transform fault, that became, at this time, an active continental transform margin segment. The active transform system is thought to have then shifted toward the thin, and weaker, oceanic crust whose stucture is apparently made of thin uppermantle-derived serpentinites and gabbroic bodies (Sage et al., 1997).

Starting from this time period, differences in depth between a thick continental border and the oceanic basin are anticipated to have led to gravitational sliding toward the south, and finally, to the creation of the CIGMR southern slope, as well to subsequent uncovering and erosion of early Cretaceous clastic sediments. A cooling episode, evidenced in late Cretaceous times by fission track analysis on Equanaute samples, indicates an age for passing the $60^{\circ} \mathrm{C}$ isotherm progressively younger downslope and toward the west. Such timing appears in good agreement with a progressive slope uncovering itself following progressive oceanic crust creation moving toward the west. Major faulting along the southern ridge slope should be expected from such a general collapse. The few fault scarps and the spectacular rock chaos observed at the base of the CIGMR central domain slope may be the records of this event.

Finally, during this time interval, the sharp contact, on the order of 5-10 km (Sage, 1994) established between the hot oceanic lithosphere and a colder continental crust should have also induced strong thermal gradients and resulted in subsequent CIGMR thermal uplift (Todd and Keen, 1989; Lorenzo and Vera, 1992). Within the Deep Ivorian Basin, coeval sedimentation and depositional arrangements have apparently recorded such an uplift, while the previous sedimentary units were tilted northward. This thermaltriggered uplift probably increased until the passage of the oceanic spreading ridge (Basile et al., 1993).

PASSIVE MARGIN STAGES. Active tectonism along the transform margin ceased when the spreading centre passed south of the Côte d'Ivoirc-Ghana Margin. The transform margin and the adjacent oceanic basin then began to subside as far as the present sea floor depth $(2010 \mathrm{~m}$ for the ridge top) as a result of thermal subsidence. Subsequently, the strong structural damming effect of the CIGMR prevented most of the African detrital sediment input to bypass from the Deep Ivorian Basin.

\section{CONCLUSIONS}

Observations and geological samples collected during the Equanaute deep dives across the Cote-d'Ivoire-Ghana Marginal Ridge southern slope provide constraints about the lithology, the depositional environment, and partly the age of the thick sedimentary pile which constitutes most of the ridge. The data also provide support for the tectonic and thermal regimes that controlled the transform ridge fabric and edification. The CIGMR southern slope consists of a deformed wedge of dominantly shallow clastics, likely to have been deposited in Early Cretaceous time. The presentday feature results from a relatively complex tectonic and subsidence story. The major stages of the transform ridge evolution, deduced from integration of geological (deep dive results) and geophysical data (chiefly seismic reflection) are as follows:

(1) A period of divergent rifting (Early Cretaceous, probably Barremian to late Aptian), characterized by dominant shallow clastic deposition on an unstable platform cut in a series of rotated blocks and rapidly subsiding halfgrabens. Concurrently, or soon after, the CIGMR initiated as a structural relief in response to active wrench tectonics at the boundaries between two sliding continental masses (western Equatorial Africa and northeastern Brazil).

(2) This resulted in a second deformational episode, recorded on the ridge top and across the southern ridge slope in an intense and striking fracturing and, chiefly upslope, in a series of drag folds, and wrench-related lineaments best explained by a general $\mathrm{N} 60^{\circ} \mathrm{E}$ right-lateral motion.

(3) Subsequent and progressive contact through time with an adjacent oceanic crust leads: (a) to a non-documented but probable southward shift of the main shear zone within an incipient Romanche oceanic/continental transform; (b) 
to a new, thermally triggered, CIGMR uplift attested by a strong erosional surface and hy drastic changes in coeval depositional arrangements; (c) to a probable general gravitational collapse of the CIGMR southern slope as documented by progressive westward uncovering of the clastic units, now directly exposed along the slope.

(4) In a final stage, whose initial timing remains to be checked, the CIGMR began to subside by normal cooling, as expected for a passive margin segment.

\section{Acknowledgements}

The authors are grateful to the captain and crew of the R.V. Nadir and the technical team of the submersible Nautile (IFREMER) for their invaluable assistance during the Equanaute cruise. Data processing was made possible by CNRS-INSU financial support (Géosciences Marines).

Contribution Number 142 of the Géosciences Azur (UMR 6526).

\section{REFERENCES}

Affaton P., J. Sougy, R. Trompette (1980). The tectono-stratigraphic relationships between the upper Precambrian and lower Paleozoic Volta basin and the pan African Dahomeyide orogenic belt (West Africa). Amer. J. Sci. 280, 224-248.

Basile C., J. Mascle, C. Auroux, J.P. Bouillin, G. Mascle, K. Gonzalves de Souza, le groupe Equamarge (1989). Une marge transformante type: la marge continentale de Côte d'Ivoire-Ghana: résultats préliminaires de la campagne Equamarge II. C.R. Acad. Sci. Paris 308, 997-1004.

Basile C. (1990). Analyse structurale et modélisation analogique d'une marge transformante: l'exemple de la marge profonde de Côte d'Ivoire-Ghana. Mém. Doc. CAESS Rennes, 39.

Basile C., J.P. Brun, J. Mascle (1992). Structure et formation de la marge transformante de Côte d'Ivoire-Ghana : apports de la sismique réflexion et de la modélisation analogique. Bull. Soc. Geol. Fr. 163 , 207-216.

Basile C., J. Mascle, M. Popoff, J.P. Bouillin, G. Mascle (1993). The Côte d'Ivoire-Ghana transform margin: a marginal ridge structure deduced from seismic data. Tectonophysics 222, 1-19.

Basile C., J. Mascle, F. Sage, B. Pontoise, G. Lamarche (1996). ODP 159 Pre-cruise surveys and Site surveys: a synthesis of marine geological and geophysical data on the Côte d'Ivoire-Ghana Transform Margin, in J. Mascle, P. Lohmann, P.D. Clift et al. Proc. ODP, Init. Repts., 159 College Station, TX (Ocean Drilling Program), 47-60.

Benkhelil J., M. Guiraud, J. Mascle, C. Basile, J.P. Bouillin, G. Mascle, M. Cousin (1996). Enregistrement structural du coulissage Afrique/Brésil au sein des sédiments crétacés de la marge transformante de Côte d'Ivoire-Ghana. C.R. Acad. Sci. Paris 323, $73-80$.

Benkhelil J., J. Mascle, M. Guiraud, C. Basile (1997). Submersible observations of cretaceous deformations along the Côte d'IvoireGhana transform margin, Geo. Mar. Lett. 17, 49-59.

Blarez E. (1986). La marge continentale de Côte d'Ivoire-Ghana: structure et évolution d'une marge continentale transformante. Ph. D. Thesis: Université Pierre et Marie Curie, Paris.

Blarez E., J. Mascle, P. Affaton, C. Robert, J.P. Herbin, G. Mascle (1987). Géologie de la pente continentale ivoiro-ghanéenne: résultats de dragages de la campagne Equamarge. Bull. Soc. Geol. France 5, 877-885.

Bouillin J.P., G. Poupeau, L. Riou, N. Sabil, C. Basile, J. Mascle, G. Mascle, the Equanaute Scientific Party (1994). La marge transformante de Cote d'Ivoire-Ghana: premières donnés thermochronologiques (campagne Equanaute, 1992). C.R. Acad. Sci. Paris 318, $1365-1370$.

Bouillin J.P., G. Poupeau, E. Labrin, Ch. Basile, N. Sabil, J. Mascle, G. Mascle, F. Fillot, L. Riou (1997). Fission track study: heating and denudation of the Côte d'Ivoire-Ghana marginal ridge. Geo-Mar. Lett. 17, 55-61.
Craig J., W.R. Fitches, A.J. Maltman (1982). Chlorite-mica stacks in low-strain rocks from central Wales. Geol. Mag. 119, 243-256.

Guiraud M., M. Séguret (1987). Soft-sediment microfaulting related to compaction within the fluvio-deltaic infill of the Soria strike-slip basin (northern Spain), in Deformation of Sediments and Sedimentary Rocks, Jones M.E., R.M.F. Preston Eds. Geol. Soc. London Spec. Pub. 29, pp. 123-136.

Guiraud M., J. Benkheli, J. Mascle, C. Basile, G. Mascle, the Equanaute Team (1997a). Syn-rift to syn-transform deformation: evidences from deep sea dives along the Côte d'Ivoire-Ghana transform margin. Geo-Mar. Lett. 17, 70- 78.

Guiraud M., J. Mascle, J. Benkhelil, C. Basile, G. Mascle, M. Durand (1997b). Early Cretaceous sedimentary environment of the Côte d'Ivoire-Ghana transform margin as deduced from deep dives data, Geo-Mar. Lett. 17, 79-86.

Honnorez J., J. Mascle, P. Tricart, Ch. Basile, M. Villeneuve H. Bertrand (1991). Mapping of a segment of the Romanche fracture zone: a morphostructural analysis of a major transform fault of the Equatorial Atlantic. Geology 19, 8, 769-864.

Jardiné S. (1967). Spores à expansions en forme d'élatères du Crétacé moyen d'Afrique occidentalc. Rev. Palaebotan. Palynol. 1, 235-258.

Klingebiel A. (1976). Sédiments et milieux sédimentaires dans le golfe de Bénin. Bull. Centre Rech. Pau-SNEAP 1, 129-148.

Lamarche G., C. Basile, J. Mascle, F. Sage (1997). The Côte d'Ivoire-Ghana transform margin: sedimentary and tectonic structure from MCS data. Geo-Mar. Lett. 17, 62-69.

Lorenzo J.M., E.E. Vera (1992). Correlation between diverse seismic and physical properties data sets: Site 763, southern Exmouth Plateau. In: von Rad U., B.U. Haq et al., Proc. ODP, Sci. Results, 122: College Station, TX (Ocean Drilling Program), 393-409.

Mascle J., A.F.J. Smit (1974). Nature de la pente continentale au Sud du Cap des Trois Pointes (Ghana, Afrique), C.R. Acad. Sci. Paris 279, 121-124.

Masele J. (1976). Lc golfc de Guinćc: un cxcmple d'ćvolution de marge atlantique en cisaillement. Mém. Soc. Géol. France, nouvelle série, L.V 128 ,

Mascle J., E. Blarez (1987). Evidence for transform margin evolution from the Côte d'Ivoire-Ghana continental margin. Nature 326, 378381

Mascle J., Equanaute (1994). Les marges continentales transformantes ouest-africaines: Côte d'Ivoire, Ghana, Guinée. IFREMER, Série Repères Océan 5, 125 p.

Mascle J., E. Blarez, M. Marinho (1988). The shallow structure of the Guinea and Cote d'Ivoire-Ghana transform margins: their bearing on the equatorial Atlantic Mesozoic evolution. Tectonophysics 155 , 193-209.

Mascle J., C. Auroux, the shipboard scientific team (1989). Les marges continentales transformantes ouest-africaines (Guinée, Côte 
d'Ivoire-Ghana) et la zone de fracture de la Romanche: Campagne Equamarge II (février-mars 1988). Campagnes Océanographiques Françaises. Publications IFREMER.

Mascle J, M. Guiraud, C. Basile, J. Benkhelil, J.P. Bouillin, M. Cousin, G. Mascle (1993). La marge transformante de Côte-d'IvoireGhana: premiers résultats de la campagne Equanaute. C.R. Acad. Sci. Paris 316, 1255-1261.

Mascle J., C. Basile, F. Sage, B. Pontoise (1995). The Côte d'IvoireGhana transform margin: an example of an ocean-continent transform boundary. E. Banda et al. Eds. Kluwer Academic Publishers, Netherlands "Rifted Ocean-Continent boundaries", pp. 327-339.

Mascle J., G.P. Lohmann P. Clift et al. (1997). Proc. ODP Init. Repts., 159, College Station, TX (Ocean Drilling Program),

Popoff M., S. Raillard, J. Mascle, C. Auroux, C. Basile, Equamarge Group (1989). Analyse d'un segment de marge transformante du Ghana: résultats de la campagne Equamarge II (Mars 1988). C.R. Acud. Sci. Paris 309, 481-487.

Ramsay J.G. (1980). The crack-seal mechanism of rock deformation. Nature 284, 135-139.

Ringrose P. (1988). Palaeoseismic (?) liquefaction event in late Quaternary lake sediment at Glen Roy, Scotland. Terra Nova 1, 57-62.

Sage F. (1994). Structure crustale d'une marge transformante et du domaine océanique adjacent: exemple de la marge de Côte d'Ivoire-Ghana. PhD Thesis: Université Paris VI.

Sage F., B. Pontoise, J. Mascle, Ch. Basile (1997). Structure of oceanic crust adjacent to a transform margin segment: example of the Côte d'Ivoire- Ghana transform margin. Geo-Marine Lett. 17, 31-39.

Todd B.J., C.E. Keen (1989). Temperature effects and their geological consequences at transform margins. Can. J. Earth Sci. 26, 2591-2603. 